\title{
Chapter 9 \\ Culture Methods of Eurasian Perch and Yellow Perch Early Life Stages
}

\author{
P. Kestemont, C. Mélard, J.A. Held, and K. Dabrowski
}

\begin{abstract}
For carnivorous species producing relatively small larvae, as Eurasian perch and yellow perch, the successful rearing of early life stages is still a matter of concern, even if significant improvements have been achieved during these last two decades. This chapter presents an overview of the different methods used to produce juveniles of these two species: (i) production of fish in fertilized ponds, with fingerling habituation to artificial feed before or after pond harvest, (ii) fertilization of mesocosms and semi-intensive production up to 45 days old, (iii) intensive production in tanks with supply of live prey progressively replaced by artificial feed. For each system, the optimal husbandry conditions as well as the influence of main factors (stocking density, temperature, growth heterogeneity and management of cannibalism, non-inflation of swim bladder,...) influencing the survival and growth of fish from larval to juvenile stages are described.
\end{abstract}

Keywords Perch $\bullet$ Larval rearing $\bullet$ Cannibalism $\bullet$ Swim bladder

\subsection{Introduction}

Several reviews dealing with the larval rearing methods of Eurasian perch (Kestemont et al. 1996, 2008; Kestemont and Mélard 2000) and yellow perch (Hart et al. 2006) have been produced during the last two decades. The culture methods

\footnotetext{
P. Kestemont ( $\square)$

Research Unit in Environmental and Evolutionary Biology, University of Namur,

Rue de Bruxelles 61, 5000 Namur, Belgium

e-mail: patrick.kestemont@unamur.be

C. Mélard

Aquaculture Research and Education Center (CEFRA), University of Liège,

Chemin de la Justice, 10, 4500 Tihange, Belgium
}

J.A. Held

University of Wisconsin-Extension Madison, Madison, WI, USA

K. Dabrowski

School of Environment and Natural Resources, Ohio State University,

2021 Coffey Rd, 43210 Columbus, OH, USA 
are rather diversified, from extensive production in ponds in Central Europe, usually targeting the polyculture of different freshwater species, mainly cyprinids, to more complex perch monoculture systems such as the tandem pond/tank rearing widely used in the north-central region of the USA, or the fully intensive larval rearing in recirculating systems as performed in several European countries.

This chapter describes the different culture methods of Eurasian perch and yellow perch early life stages and, for each method, discusses the main driving factors to be considered for optimizing the rearing performances.

\subsection{Pond Culture of Yellow Perch and Eurasian Perch}

In Europe, pond production of Eurasian perch is practiced in several countries or regions such as the North of France, Ireland, Czech Republic, Hungary and Poland. In some operations, particularly in central and Eastern Europe, pond culture is not limited to juvenile production, but continues up to market size fish, while, in other facilities, larvae are stocked in ponds up to the juvenile stage, and then harvested and subsequently trained in tanks (Kestemont et al. 2008). However, mass production of Eurasian perch early life stages is mainly performed under intensive tank conditions, allowing for year-round production of juveniles. Alternatively, most yellow perch fingerlings destined for commercial food-fish operations are produced using a tandem pond-tank protocol (Hartleb et al. 2012). In this method, fertilized ponds are employed to rear yellow perch from hatch to the juvenile stage (18$30 \mathrm{~mm}$ total length, TL), then the fingerlings are harvested from the ponds and placed into tanks for habituation to formulated feeds (Heidinger and Kayes 1986). Once the habituation process is completed, the fingerlings are returned to ponds or stocked into tanks for grow out to market size. This tandem pond-tank culture is also successfully applied in Ireland and Czech Republic with Eurasian perch.

Production ponds for both Eurasian and yellow perch fingerlings range from 0.1 to 0.8 ha. Although ponds smaller than 0.1 ha can be used to culture perch fingerlings, constructions costs for a commercial scale operation based on such ponds may be economically unfeasible. Fingerling ponds larger than 0.8 ha can be productive but they can be unwieldy to manage and harvest. Ponds can be lined or unlined, drainable or undrainable. Unlined (earthen bottom) ponds are preferred due to limited construction costs and the capability to provide a substrate for zooplankton eggs, thus ensuring continuing populations of forage. In some applications lined ponds are necessary, however, plastic liners are expensive and lined ponds usually require inoculations of phyto- and zooplankton to produce an adequate food web for concentrated fingerling production. Fingerling production ponds are generally 1.5-4 $\mathrm{m}$ deep with steeply sloped sides to eliminate shallow littoral zones that encourage the growth of rooted macrophytes.

Drainable ponds provide easy access to fingerlings at harvest and can be dried during the off-season to help control feral fish populations, aquatic nuisance species, parasites and disease vectors. The bottoms of drainable ponds are sloped 


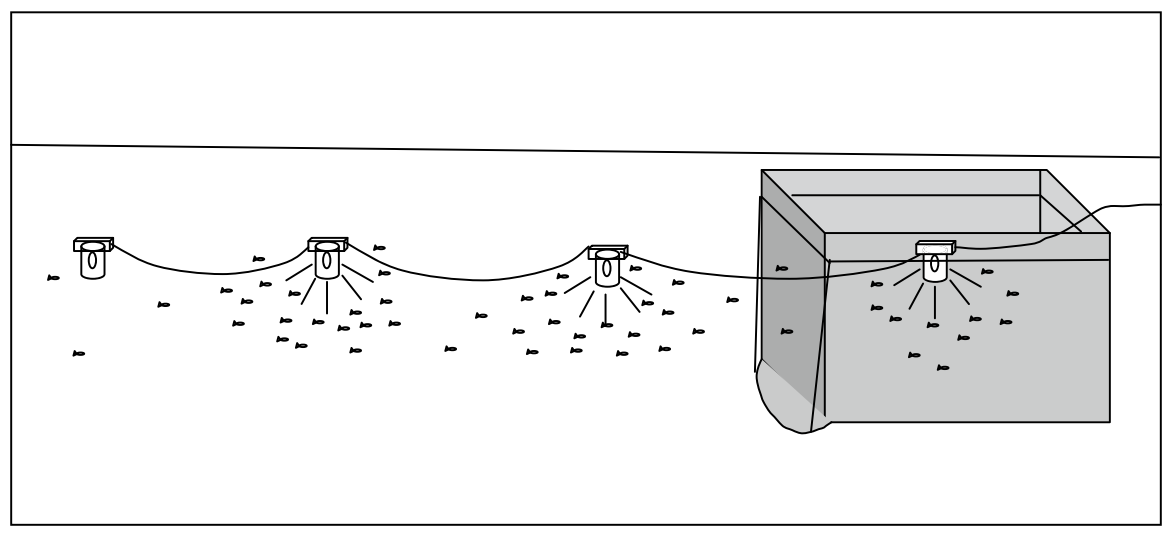

Fig. 9.1 Using lights to trap small yellow perch fingerlings from a pond at night

toward the drain to promote a rapid discharge of water during the final stages of drawdown and flush the fingerlings from the pond. Undrainable ponds require seines or traps for harvest and eradication of all remaining fish in the pond prior to use the following season. Undrainable ponds also tend to support populations of snails that can act as intermediate hosts for digenetic trematodes.

One method of removing small fingerlings from undrainable ponds uses lights at night to attract the highly photopositive fish into a box net (Fig. 9.1). A series of lights suspended under floats is distributed in the pond so that the final light is located in the box. Initially all lights are turned on and schools of fish are attracted. Over the course of approximately $30 \mathrm{~min}$ the lights are sequentially extinguished until only the light in the trap is lit. The fish follow the lights into the trap and the open side of the box is pulled shut, capturing the fingerlings. This technique is limited to small ( $<35 \mathrm{~mm}$ TL) fingerlings; as the perch grow beyond $35 \mathrm{~mm}$ TL they become less phototactic. While not as efficient as seining, the light harvest technique can be effective for the partial harvest of ponds or in situations where seines are not practical, and is a very low stress method of collection.

\subsubsection{Pond Fertilization}

The most critical aspect to the successful pond production of fingerlings is fertilization. Pond waters are supplemented with organic materials or plant nutrients to stimulate the development of decomposer or phytoplankton populations at the food web base and eventually provide prey for the developing fish. Fertilization protocols vary widely between yellow perch culturists but generally fall into three categories: organic, inorganic or a combination of the two.

Organic fertilizers are any material of direct or indirect plant origin that is subject to microbial decomposition (Soderberg 2012). Commonly used organic fertilizers include 
dried or fresh plant material such as hay or straw, animal manures, seed residues such as soybean or cottonseed meal, and yeast. Some protocols call for a terrestrial crop to be planted in the dried pond bottom that later decomposes when the pond is flooded.

In general, organic fertilizers support a food web primarily based on heterotrophic bacteria and fungi that zooplankton directly feed on (Tice et al. 1996; Morris and Mischke 1999). The release of nitrogen and phosphorus from heterotrophic decomposition can stimulate secondary production of phytoplankton that is also fed upon by zooplankton (Hartleb et al. 2012). Decomposition of the organic material can lead to dissolved oxygen depletion, particularly at the bottom of the pond. At low dissolved oxygen levels $(<1 \mathrm{ppm})$ aerobic bacteria, whose activity results in nontoxic end products can be limited by the lack of oxygen and replaced by anaerobic decomposers whose activity results in hydrogen sulfide that is highly toxic to fish. Furthermore, an abundance of aerobic decomposition can have a negative impact on the overall dissolved oxygen levels of the pond. Accordingly, aeration, water circulation and oxygen monitoring are important management activities when using organic fertilization protocols.

Boyd (1977) noted that because of their slow release of nutrients, organic materials are not as good as inorganic fertilizers at creating the large, fast algal blooms that are needed during a short larval production period. Hartleb et al. (2012) observed that the slow release of nutrients by organic materials makes it difficult to respond to environmental changes that may impact phytoplankton populations. Additionally, the delayed release of nutrients (particularly phosphorus) from organics applied late in the fingerling production cycle can stimulate the formation of filamentous algae, which is problematic during pond harvest. The observations of Boyd and Hartleb et al. are particularly important to yellow perch fingerling culture because the pond phase of production is relatively short in duration (5-7 weeks) and yellow perch fingerlings are usually harvested at a small size for habituation to formulated feed.

Inorganic fertilizers are materials high in soluble amount of nitrogen, phosphorus and potassium, or combinations of such plant nutrients; although potassium is generally not considered limiting in aquatic culture (Soderberg 2012). Common inorganic fertilizers include urea, ammonium phosphate, phosphoric acid, and a variety of complex agricultural fertilizers such as triple superphosphate. Inorganic fertilizers support an autotrophic food web by supplying nutrients that increase the abundance of algae for zooplankton consumption. While algae require numerous macro- and micronutrients to thrive, they are most commonly limited by inadequate levels of nitrogen and phosphorus (Boyd 2012). Carbon availability is generally not thought of as a limiting factor in aquatic ecosystems (Boyd 2012). Agricultural lime (calcite or dolomite), however is employed in some fertilization protocols to increase the alkalinity and hardness of acidic waters and thereby increase the effectiveness of the phosphorus additions. Since solar energy input is critical to photosynthesis, a lack of sunshine can also limit algal production (Neal and Kröger 2012).

Inorganic fertilization regimens are designed to support sustained zooplankton and benthic populations, and are used in combination with varying fry stocking densities to produce desired fingerling quantity and quality (Hartleb et al. 2012). A considerable amount of research has been conducted to develop inorganic fertiliza- 
tion protocols for the production of walleye fingerlings (see Tice et al. 1996; Culver 1996; Jacob and Culver 2010). These methods are generally applicable to yellow perch fingerling production (Soderberg 1977).

Variables such as timing the initiation and frequency of fertilizer application, desired nutrient levels and relative amounts of nitrogen and phosphorus all have implications for the successful culture of yellow perch fingerlings. Because of their small size at hatch and correspondingly small mouth gape, providing the appropriate organisms for first feeding is critically important to success culturing yellow perch fingerlings. Published reports on larval yellow perch feeding indicate that rotifers, copepod nauplii and adult copepods are important initial food sources (Siefert 1972; Bremigan et al. 2003; Fulford et al. 2006). Hartleb (2003) found larval diet selection included benthic insects, ostracods and green algae, although the presence of green algae in the diet coincided with poor growth and high mortality.

The time interval between pond filling with the associated initial application of fertilizer and fry stocking should be managed to assure an abundance of small prey for the larval fish. This interval is generally $3-10$ days but will vary with a number of factors including water source, water temperature and fertility of the pond substrate. Poor results will be experienced if fry stocking occurs after rotifer and copepod nauplii populations decline in favor of larger copepods and cladocerans.

Culver (1996) recommended a nitrogen to phosphorus (N:P) ratio of 20:1 by weight with no more than $30 \mu \mathrm{g}$ of $\mathrm{P} \mathrm{L}^{-1}$. This ratio favors the production of small algae that is most easily consumed by crustacean zooplankton; the low concentrations of $\mathrm{P}$ limit the production of large blue-green and green filamentous species. Culver (1996) also suggested weekly additions of inorganics based on water quality analysis to maintain the N:P balance, however water quality monitoring at the Lake Mills State Fish Hatchery (Lake Mills, WI) indicated that nitrogen was virtually consumed within 3 days. A protocol employing twice-weekly applications was adopted to maintain the proper N:P ratio in walleye fingerling ponds (Robert Fahey Wisconsin Department of Natural Resources, pers. com.). After approximately 3 weeks, phosphorus begins to recycle from decaying plant material and in many cases phosphorus additions are discontinued to maintain N:P ratios and limit the growth of filamentous algae (Hartleb et al. 2012).

Table 9.1 compares the species distribution and relative abundance of zooplankton sampled from yellow perch fingerling production ponds fertilized with either organic or inorganic regimens. The organic protocol called for an initial application of soybean meal at a rate of $336.3 \mathrm{~kg} \mathrm{ha}^{-1}$ with weekly additions of $112.1 \mathrm{~kg} \mathrm{ha}^{-1}$. The inorganic protocol employed initial applications of $35.9 \mathrm{~kg} \mathrm{ha}^{-1}$ urea, $9.4 \mathrm{~kg} \mathrm{ha}^{-1}$ triple superphosphate and $197.3 \mathrm{~kg} \mathrm{ha}^{-1}$ agricultural lime with weekly additions of $23.5 \mathrm{~kg}$ $\mathrm{ha}^{-1}$ urea, $4.0 \mathrm{~kg} \mathrm{ha}^{-1}$ triple superphosphate and $89.7 \mathrm{~kg} \mathrm{ha}^{-1}$ agricultural lime. As can be seen from the data the inorganic protocol resulted in roughly 3.5 times the number of small prey (rotifers and juvenile stages of copepods) and 1.5 times the number of large prey (adult copepods and cladocerans as the organic treatment.

Of course, this is not the whole story. Availability of appropriate sized prey for the growing fingerlings is critical to success. Figure 9.2 describes the zooplankton populations of the two treatments at each of the sampling points. The inorganic 
Table 9.1 Relative abundance of zooplankton in yellow perch fingerling production ponds using organic and inorganic fertilization regimens. The data represents the mean organisms $\mathrm{L}^{-1}$ and S.E.M. of four ponds per treatment sampled six times at weekly intervals from fry introduction to harvest

\begin{tabular}{|c|c|c|}
\hline & Organic fertilization & Inorganic fertilization \\
\hline \multicolumn{3}{|l|}{ Rotifera } \\
\hline Asplanchna spp. & $20.0 \pm 6.5$ & $51.0 \pm 37.7$ \\
\hline Brachionus spp. & $7.3 \pm 3.0$ & $80.8 \pm 43.7$ \\
\hline Filinia terminalis & $1.1 \pm 0.4$ & $18.0 \pm 8.6$ \\
\hline Keratella spp. & $340.3 \pm 121.7$ & $1414.5 \pm 575.1$ \\
\hline Polyarthra spp. & $21.4 \pm 11.4$ & $46.5 \pm 19.5$ \\
\hline Synchaeta spp. & $9.5 \pm 2.9$ & $43.6 \pm 29.0$ \\
\hline Misc.Rotifers & $2.0 \pm 1.1$ & $0.6 \pm 0.3$ \\
\hline Total & 401.6 & 1655.0 \\
\hline \multicolumn{3}{|l|}{ Copepoda (Juvenile) } \\
\hline Copepodites & $6.2 \pm 3.6$ & $16.1 \pm 8.2$ \\
\hline Nauplii & $137.8 \pm 42.6$ & $205.7 \pm 57.0$ \\
\hline Total & 144.0 & 221.8 \\
\hline \multicolumn{3}{|l|}{ Copepoda (Adult) } \\
\hline Calanoid Copepods & $1.1 \pm 0.6$ & $0.6 \pm 0.4$ \\
\hline Cyclopoid Copepods & $5.9 \pm 3.4$ & $26.6 \pm 13.2$ \\
\hline Harpactoid Copepods & $0 \pm 0$ & $0 \pm 0$ \\
\hline Total & 7.0 & 27.2 \\
\hline \multicolumn{3}{|l|}{ Cladocera } \\
\hline Bosmina longirostris & $4.4 \pm 1.8$ & $6.9 \pm 3.0$ \\
\hline Chydoridae & $5.3 \pm 1.4$ & $1.7 \pm 1.0$ \\
\hline Daphnia spp. & $14.4 \pm 4.5$ & $12.2 \pm 6.6$ \\
\hline Misc Cladocerans & $4.2 \pm 1.4$ & $1.5 \pm 0.5$ \\
\hline Total & 28.3 & 22.3 \\
\hline
\end{tabular}

protocol resulted in considerably higher numbers of small prey during the first 1-3 weeks of culture and slightly higher numbers of large prey during the final weeks of culture. The wide variability between ponds and the limited number of replicates makes it difficult to draw meaningful conclusions using standard statistical methods, however the trends, especially for the small prey, appear obvious. To the producer the only meaningful measure of success is the number of fish produced. In this study, the ponds using the inorganic protocol averaged approximately $437,000 \pm 127,000$ fingerlings $\mathrm{ha}^{-1}$ and the organic 310,000 $\pm 80,000$ fingerlings $\mathrm{ha}^{-1}$. Survival averaged $70 \%$ and $49 \%$ for inorganic and organic ponds, respectively. All ponds were stocked at a rate of a 673,000 fry ha $^{-1}$ and ranged in size from 0.04 to 0.57 ha.

Combined fertilization protocols rely on both organic and inorganic fertilizers. This method provides for the development of multiple webs as well as the ability to respond to environmental changes (Hartleb et al. 2012). Combined fertilization techniques are the same as inorganic methods with the exception of initial and supplemental applications of organics. The organics support the heterotrophs and 

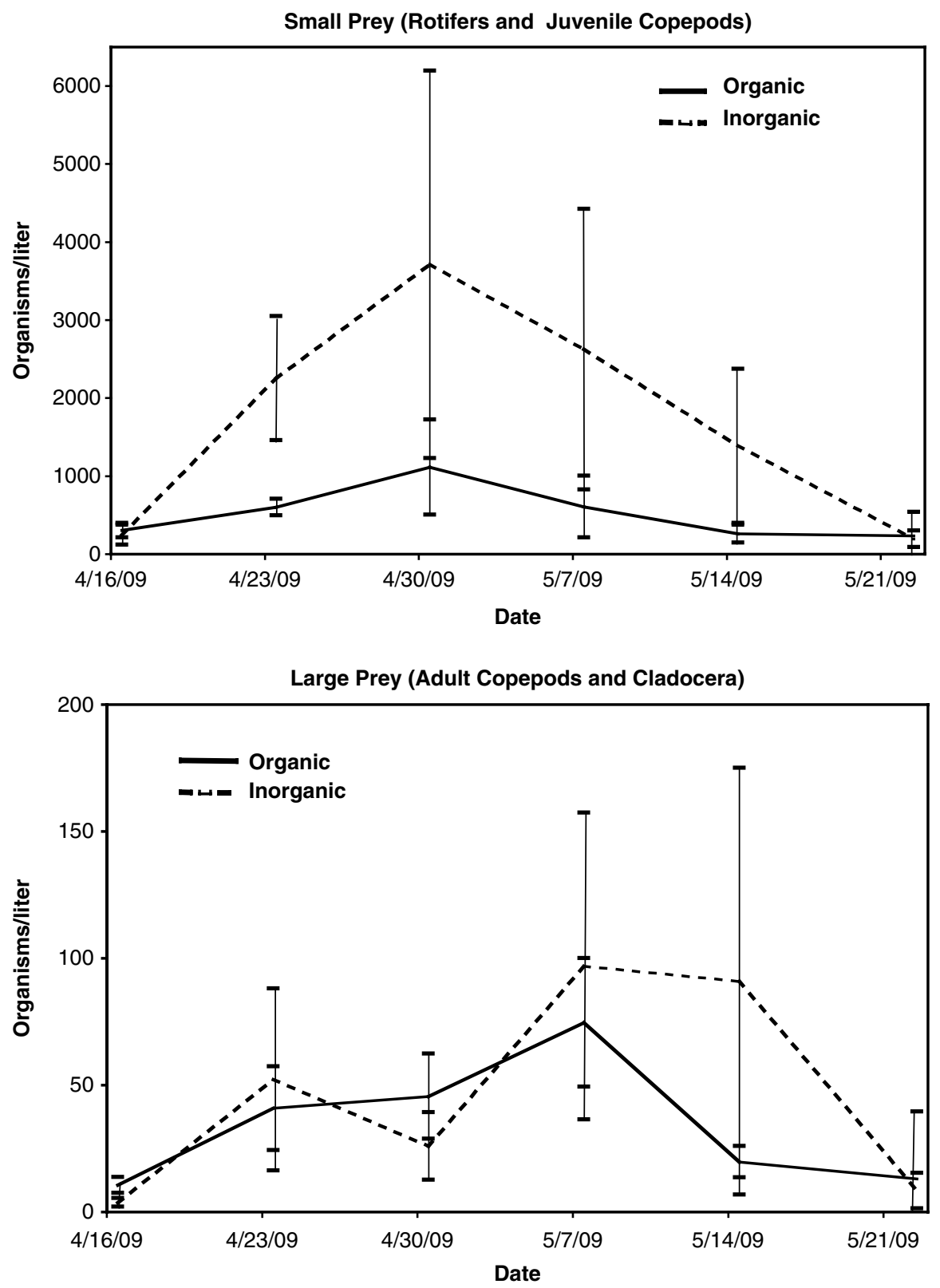

Fig. 9.2 Abundance of small (top graph) and large (bottom graph) prey over the course of the culture period in yellow perch fingerling production ponds fertilized using organic and inorganic fertilization protocols. The data represents the mean \pm S.E.M. of $n=4$ ponds/treatment 
the secondary release of nitrogen and phosphorus from decomposition is accounted for in the water quality monitoring of the inorganic protocol. While the combined method results in the use of less chemical fertilizers, its advantage may be limited to years in which a lack of sunshine results in poor algae production (Hartleb et al. 2012) and therefore a greater reliance on the heterotrophic food web.

\subsubsection{Larval Stocking Density, Survival and Growth of Eurasian Perch in Ponds}

Depending on climatic conditions prevailing in European countries, pond stocking of newly hatched larvae is usually undertaken from late March to late April. Alternatively stocking can be accomplished with fertilized eggs at the eyed stage approximately 1-2 days prior to hatching. In this case eyed eggs are placed in small floating cages $(0.4 \times 0.4 \times 0.4 \mathrm{~m})$ with small mesh sizes $(1.5 \mathrm{~mm})$ retaining the eggs but allowing the passage of hatched larvae. Fertilized ribbons can also be draped over supporting branches laid throughout the pond (Kestemont et al. 2008). Pond stocking rates for Eurasian perch are highly variable ranging from 10,000 to 60,000 eyed eggs per $100 \mathrm{~m}^{2}$.

Several studies have shown that the production of juveniles in ponds rarely exceeds $1,000-5,000$ juveniles per $100 \mathrm{~m}^{2}$ at a mean body weight of $0.5-1.5 \mathrm{~g}$ after 2 months of culture regardless of initial larval stocking density. This represents a survival rate of 5-20\%. Ponds should be stocked with egg ribbons or larvae that are close in age to reduce size heterogeneity and the potential impact of cannibalism caused by early-hatched fish (more details on cannibalism in perch are provided in Sect. 9.3.3). High stocking densities induce a rapid depletion of natural resources and, consequently, the emergence of cannibalistic behavior. A regular assessment of zooplankton populations allows for identification of harvest times whereby fingerlings are harvested before complete zooplankton population declines, resulting in fewer instances of in-pond cannibalism (Kestemont et al. 2008). In Ireland, the practice is to remove Eurasian perch juveniles after about 8 weeks (mid to late June), at a body weight of $<0.5 \mathrm{~g}$, for feed training in tanks. At this stage, fish display shoaling behavior, and the shoals usually contain fish of the same size, limiting the need for initial grading when transferred into tanks.

\subsubsection{Yellow Perch and Eurasian Perch Fingerling Habituation}

Habituation of yellow perch fingerlings to formulated feeds and intensive culture conditions is an important step in the production protocol. In this process, yellow perch fingerlings are harvested from production ponds, concentrated in tanks and trained to accept formulated feed. Once trained, the fingerlings can be stocked into ponds or tanks for grow out to market size. 
Pond stocking rates for yellow perch fry range from 375,000 to $1,500,000$ fish $\mathrm{ha}^{-1}$ depending on production goals. Stocking rates determine the length of time fingerlings can remain in the pond before food requirements of the fish exceed available zooplankton populations. Lower stocking rates allow a longer pond phase and therefore larger fingerlings. Larger ( $>35 \mathrm{~mm}$ TL) fingerlings, however, are not necessarily the most desirable subjects for habituation to formulated feed. Malison and Held (1992) found no difference in the habituation success of yellow perch when comparing well-conformed fish averaging 16.9, 32.5, and $42.6 \mathrm{~mm}$ TL. Held et al. (1998) demonstrated that a combination of high fry stocking densities $(1,000,000$ fry $\mathrm{ha}^{-1}$ ) and early pond harvest, when fish reach $17-25 \mathrm{~mm}$ TL, resulted in production as high as 494,193 fish ha ${ }^{-1}$ of which $50-70 \%$ can be habituated to formulated feed. The physical condition and body conformation of harvested fingerlings are important to habituation success. Predictably, efforts at habituating overly stressed or starving emaciated fingerlings regardless of length results in very poor success.

Another important consideration in deciding what size fingerling to harvest is the duration of the habituation period, that is, the number of days it takes for all fish in the cohort to be actively feeding on the formulated diet. Most commercial yellow perch fingerling operations are limited by tank space to undertake the habituation process. Far more perch fingerlings can be produced in ponds than can be accommodated in tanks for habituation at any one time. Accordingly, a short habituation period allows fish to be advanced through the process more rapidly, resulting in more feed-trained fish over the course of the season.

Recording daily mortalities in the habituation tanks will help to define the end of the habituation period. Since the fish in each cohort are virtually the same size, those not accepting the formulated diet will starve and die within days of each other; a graph of daily mortalities will show a well-defined peak (Fig. 9.3). Malison and Held (1992) found that yellow perch harvested at $16.9 \mathrm{~mm}$ TL required 13 days to complete the habituation process, yellow perch at $32.5 \mathrm{~mm}$ TL required 32 days and fish at $42.6 \mathrm{~mm}$ TL required 47 days (Fig. 9.4).

Recent modifications of the habituation protocol developed by researchers at the University of Wisconsin Aquaculture Program (Lake Mills, WI) have resulted in habituation success rates of 80-90\% and are currently in practice by several yellow perch culturists. The use of freeze-dried krill as an attractant in combination with the formulated diet has demonstrated noticeably improved initial acceptance of the food. Yellow perch fingerlings respond to the krill within hours of harvest rather than days as previously experienced with formulated feed alone. Malison and Held (1992) found that subdued internal tank lighting improved the habituation success of yellow perch fingerlings. Acting on these results, commercial culturists have employed internal lighting or dim overhead lighting during habituation to reduce the agitated activity of perch fingerlings responding to shadows and movement near the tanks (David Northey Coolwater Farms LLC, pers. com.).

Other modifications of the habituation protocol employed by culturists at Coolwater Farms (Cambridge, WI) include partial (seine) harvest of fingerling production ponds and the use of micro ponds. Coolwater Farms culturists remove a portion of the fingerling population from production ponds at the smallest practical 


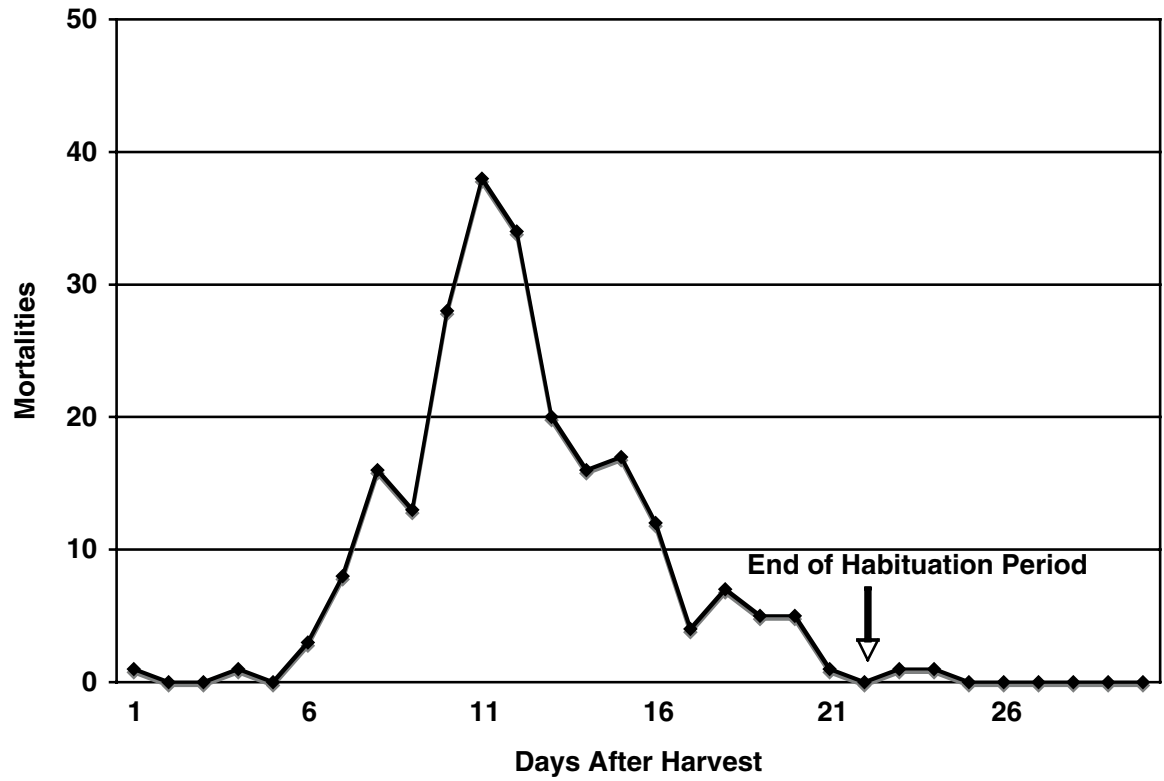

Fig. 9.3 Typical mortality curve generated from in-tank habituation of yellow perch fingerlings harvested from ponds at $21 \mathrm{mmTL}$. The data represents the number of mortalities removed from the tank each day

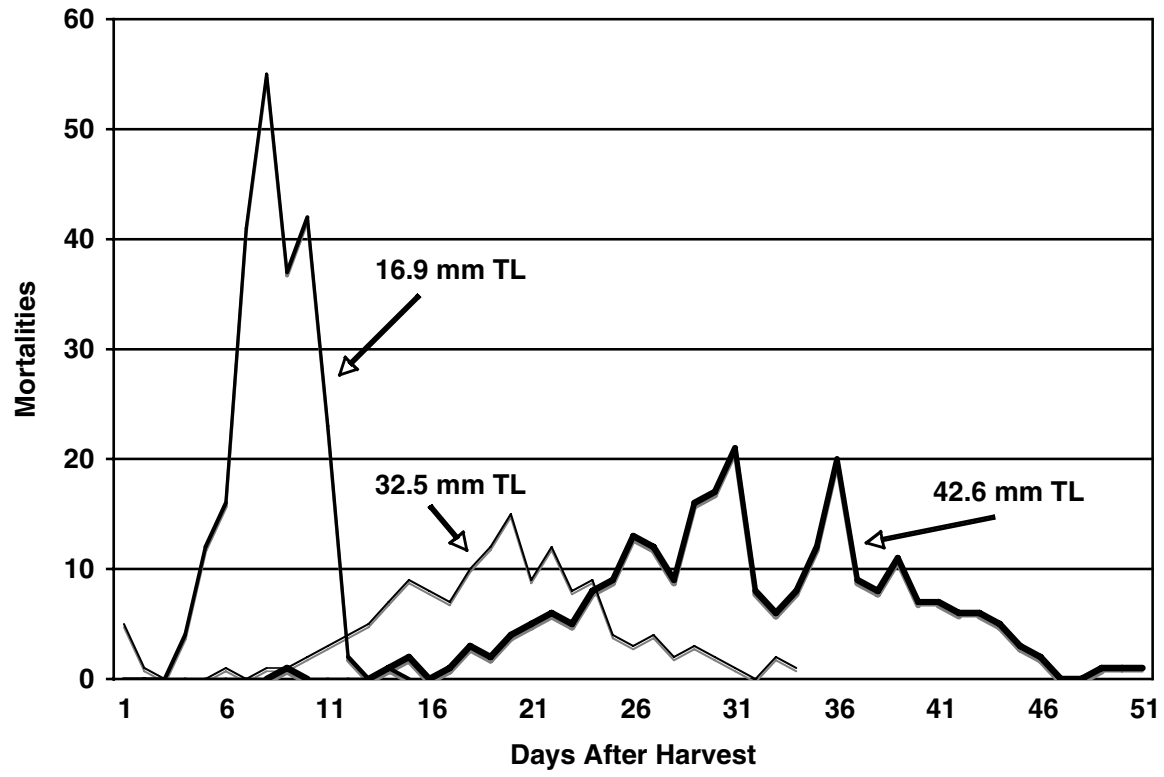

Fig. 9.4 Mortality curves during in-tank habituation for yellow perch fingerlings harvested from pond at 16.9, 32.5, and 42.6 mmTL (Data from Malison and Held (1992)) 
size for tank habituation ( $20 \mathrm{~mm} \mathrm{TL})$ thereby reducing the predation pressure on zooplankton populations in the ponds. At this time in-pond feeding is initiated to supplement natural productivity and expose the remaining fingerlings to formulated feed. The harvested fingerlings are habituated in tanks for 4-7 days and then transferred to very small $\left(12 \mathrm{~m}^{2}\right)$ micro ponds for a further 7 days of habituation and conditioning to outdoor conditions. Finally the fish are released to the grow out pond. Using this protocol, limited tank space can be reallocated to a new harvest of juveniles and the semi-habituated fingerlings can experience a transition from indoor to outdoor culture. A significant number (approx. 5-15\%) of habituated fingerlings will revert to natural forage when released to grow out ponds without this transition. At the end of the first season of growth, these foragers can be easily identified by their small size and vivid coloration.

Habituation of yellow perch fingerlings can also be undertaken in ponds, initially using lights at night to attract the highly photopositive fingerlings to vibrating feeders that distribute diet at frequent intervals. Ultimately, feeding can be extended to daylight hours with fish being attracted by the vibration of the feeders. In-pond techniques eliminate the need for indoor tank facilities and the considerable husbandry associated with tank habituation. Additionally, in-pond habituation allows for earlier exposure of formulated feed to fingerlings that are too small and delicate to harvest and an extended transition from natural to formulated diet. In this protocol, production as high as 615,000-trained fingerlings ha $^{-1}$ has been documented (Malison et al. 1994). Subsequent (unpublished) trials of this technique have indicated that harvest and size grading of the habituated fingerlings was necessary to maintain a uniform size cohort and avoid social dominance and potential cannibalism (Fig. 9.5).

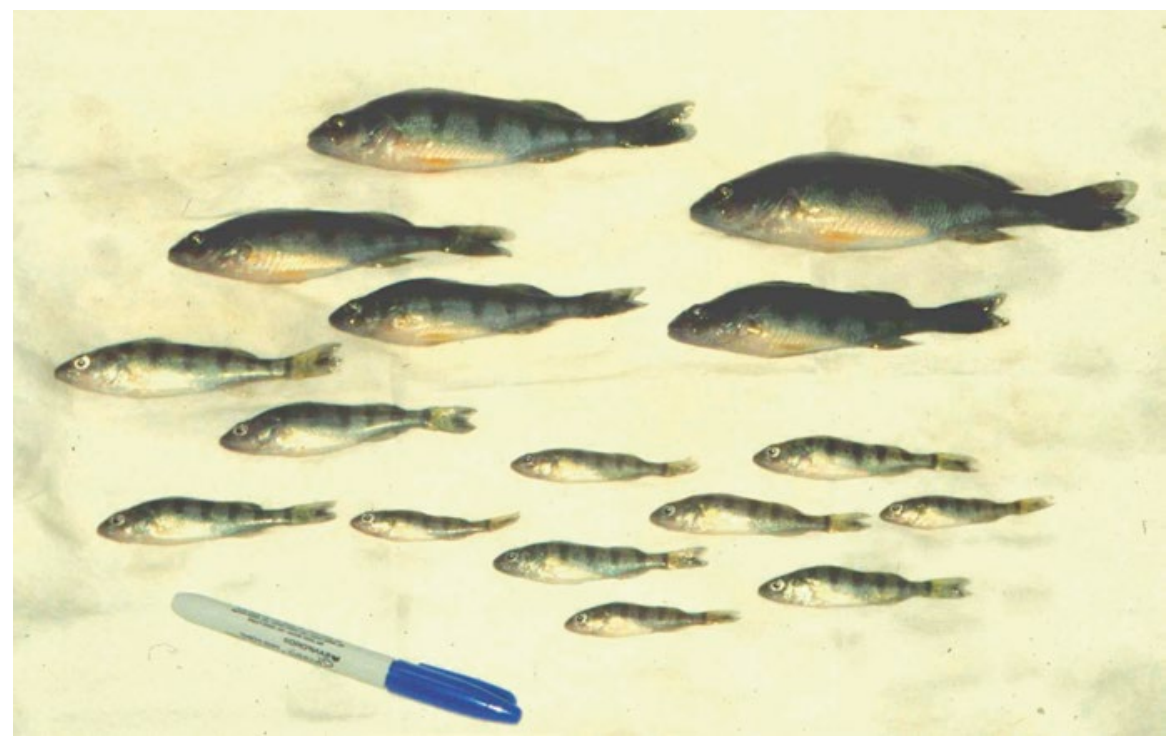

Fig. 9.5 Typical size distribution of yellow perch after 6 weeks of in-pond habituation 


\subsection{Semi-intensive Culture in Mesocosms}

The mesocosm (green water) system is one of the optimal culture systems for the production of weaned perch (Perca fluviatilis) fry under semi-intensive conditions (Mélard et al. 1996; Kestemont et al. 1996). At the end of the larval rearing period, survival ranges from $20 \%$ to $40 \%$ depending on culture conditions (initial stocking density, temperature, rotifer abundance) and the intensity of cannibalism. No deformities were recorded in Eurasian perch reared in this semi-intensive fertilized system. Good survival rates and fry quality probably result from the initial access to live preys: rotifers, protozoa and algae. Algae have been considered to be beneficial to larval fish during the first feeding, even in carnivorous fish like perch (Nash et al. 1974; Dabrowski 1984).

\subsubsection{Rearing Method}

A large set of experiments aimed at determining optimal rearing methods and culture conditions are summarized hereafter. Larval rearing facilities consisting of rectangular $10 \mathrm{~m}^{2}\left(5 \mathrm{~m}^{3}\right)$ out-door concrete tanks were supplied with river water, or better with de-saturated pathogen-free well water during a 44-days rearing period. Water temperatures ranged from 17 to $23^{\circ} \mathrm{C}$. Air diffusers placed in each tank maintained the oxygen level around $8 \mathrm{ppm}$. The tanks were fertilized with an initial single input of $1.5 \mathrm{~kg}$ of chicken manure pellets put in a basket that stimulated the development of phytoplankton then zooplankton (rotifers) (Fig. 9.6). Chicken manure pellets were removed after 4-5 days. During the 7-day fertilization period, the temperature was maintained at $24-25{ }^{\circ} \mathrm{C}$ (heating system, green-house) to accelerate and increase the plankton production. During this period no water renewal was applied. Since young perch are unlikely to survive handling at the larval stage, ready-to-hatch eyed perch eggs were stocked on trays in the tank at day 8 after tank fertilization, when the availability of zooplankton is at its maximum (density up to 2,500 rotifers $\left.\mathrm{L}^{-1}\right)$. Five days after hatching, the tanks were partly $(80 \%)$ shaded to prevent any further development of filamentous algae that may trap larvae. During the first days, water renewal rate was null to prevent the flushing of algae and rotifers. Tanks were then progressively transformed to flow through systems with water renewal rates from 1 to $2 \mathrm{~m}^{3} \mathrm{~h}^{-1}$ depending on stocking density and biomass increase.

Fish were fed with Artemia nauplii 2 days after hatching as a complementary food to rotifers. Depending on initial larval stocking density, rotifers were completely consumed by Eurasian perch larvae 2-4 days post-hatching. The weaning period extended from the 7th to the 30th day of feeding during which Artemia nauplii were progressively replaced by formulated larval dry diet (54\% protein content), then by a standard fry trout diet (50\% protein content). Food distribution was exclusively diurnal using automatic feeders for formulated diets and manual distribution (four times daily) for Artemia nauplii. Feed introduction took place in the 


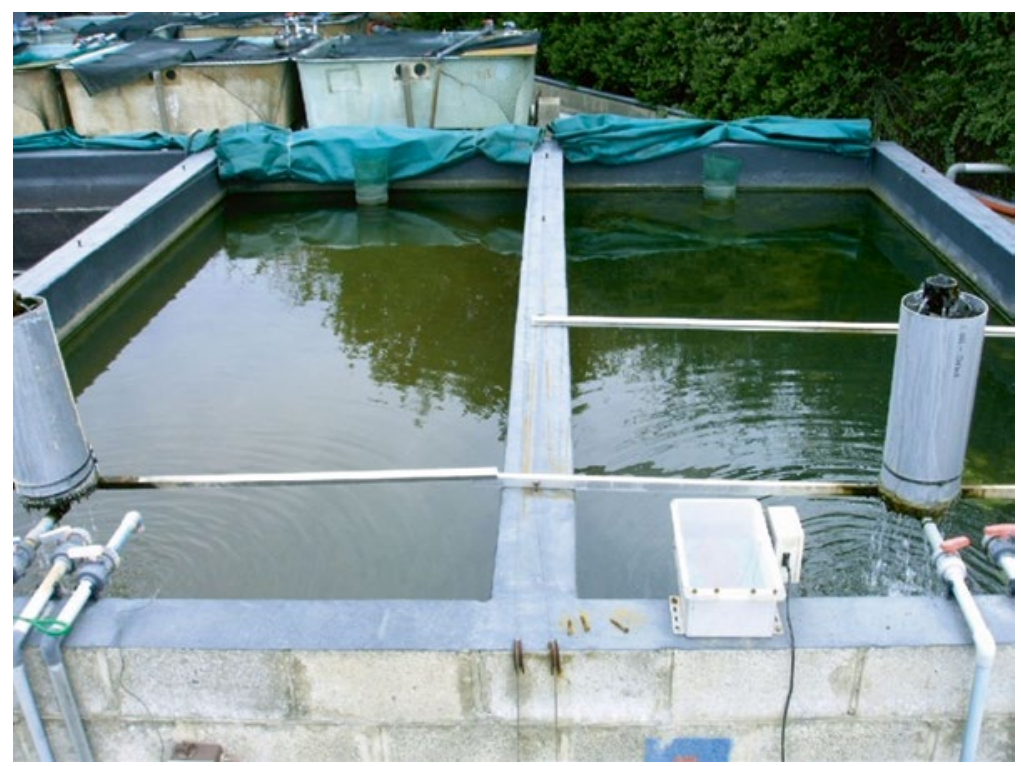

Fig. 9.6 Mesocosms used for the semi-intensive (green water) rearing of Eurasian perch larvae, after fertilization with chicken manure

non-shaded area of the tank. The use of high quality larval formulated feed could probably reduce or even suppress the use of Artemia but to date this substitution has not been tested with Eurasian perch. Fish were fed close to the maximum food ration determined from the following equation:

$$
\mathrm{R}(\% \text { body weight })=45.902 \mathrm{~W}^{-0.265}, \mathrm{~W}=\text { body weight }(\mathrm{mg}) \text {. }
$$

At the end of the 44-day rearing period, fish were collected and graded for the first time into two categories, based on an obviously bimodal size and weight distribution (Fig. 9.7). Fast growing fish were ranked as potential cannibals.

\subsubsection{Optimal Temperature and Stocking Densities}

At stocking densities ranging from 400 to 4,000 larvae $\mathrm{m}^{-2}$, growth is negatively correlated with stocking density at $20^{\circ} \mathrm{C}$, but positively at $23{ }^{\circ} \mathrm{C}$ (Fig. 9.8). Growth rate of fish is clearly enhanced at $23{ }^{\circ} \mathrm{C}$. However, survival rate is lower $($ mean $=18.7 \%)$ at $23{ }^{\circ} \mathrm{C}$ than at $20^{\circ} \mathrm{C}($ mean $=29.2 \%)$ (Fig. 9.9).

Regardless of temperature, coefficient of weight variation and proportion of cannibals are reduced at high stocking densities (Fig. 9.9): the number of cannibals when plotted against stocking density describes a semi-logarithmic relationship (Fig. 9.10). Cannibals represent $\pm 2 \%$ of the final population at initial stocking den- 


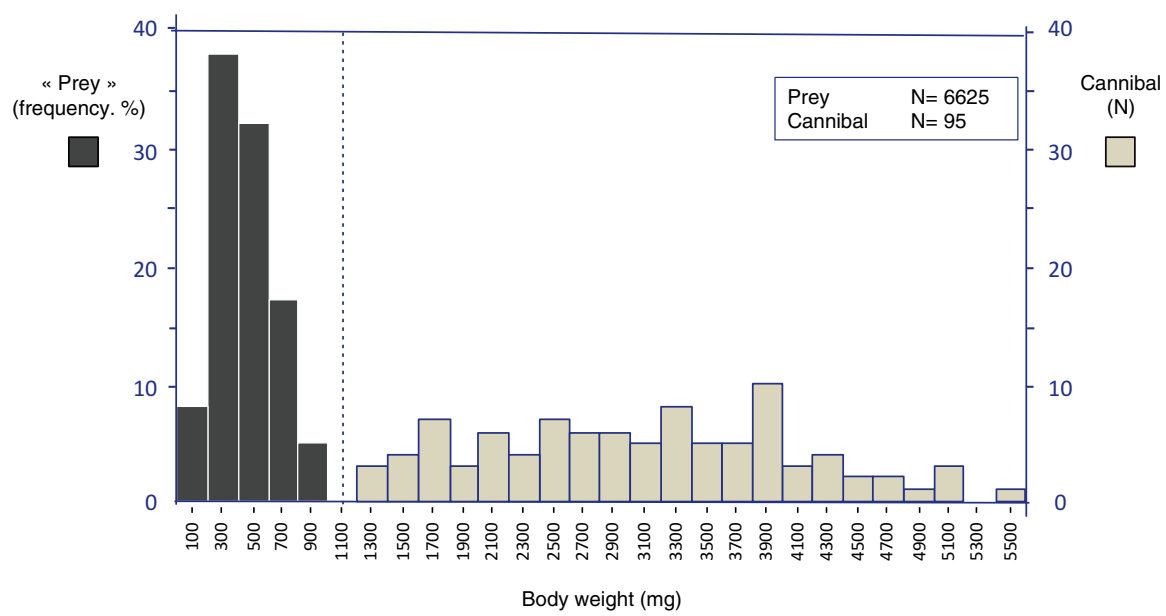

Fig. 9.7 Typical bimodal weight distribution at the end of the rearing period (44 days) (From Mélard et al. (1996))

a

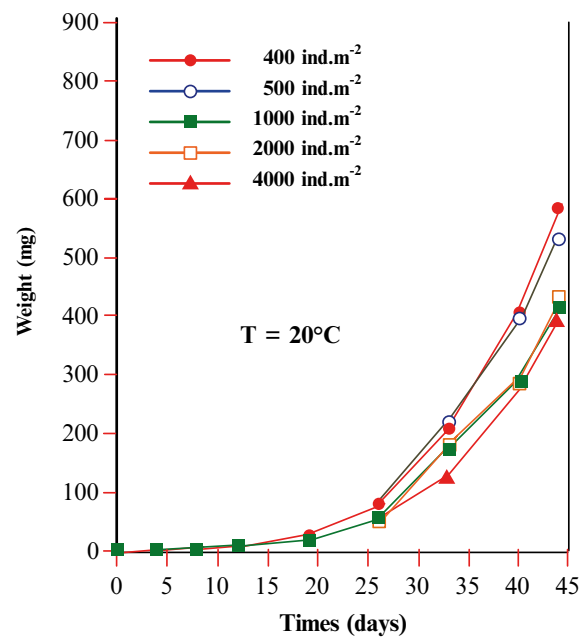

b

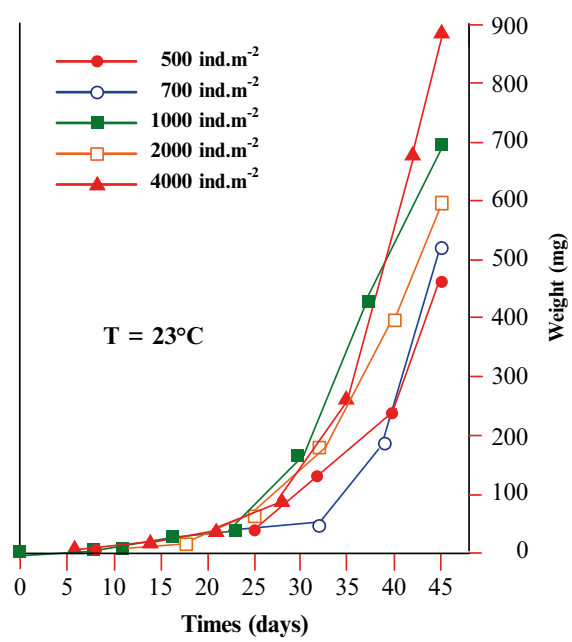

Fig. 9.8 Effects of stocking density and temperature on the growth of perch larvae in semiintensive system (From Kestemont et al. (1996))

sity of 4,000 larvae $\mathrm{m}^{-2}$ and $\pm 4 \%$ at 500 larvae $\mathrm{m}^{-2}$. This model clearly recommends increasing stocking density as much as possible to reduce the impact of cannibalism and attain the optimum growth-survival combinations. Still, it should be emphasized that higher stocking densities up to 4,000 larvae $\mathrm{m}^{-2}$ would probably generate physicochemical conditions beyond the tolerance range of Eurasian perch larvae. Similarly, the quantity of live natural planktonic prey in the rearing system is lim- 


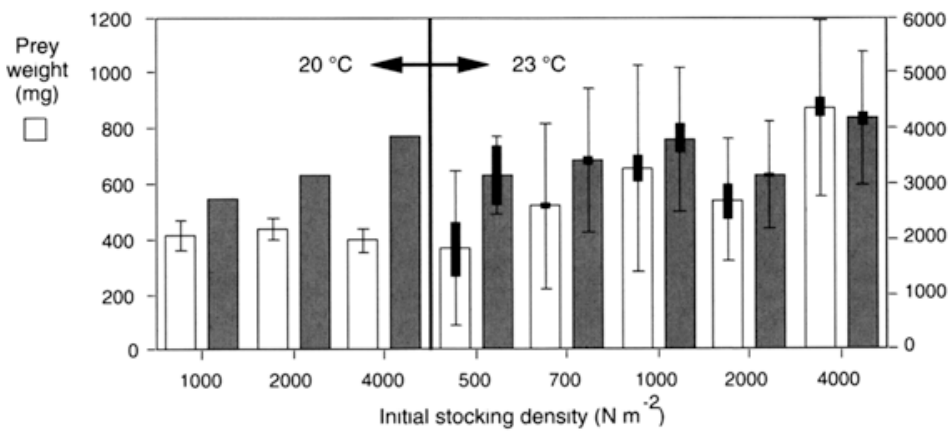

Cannibal

weight (mg)
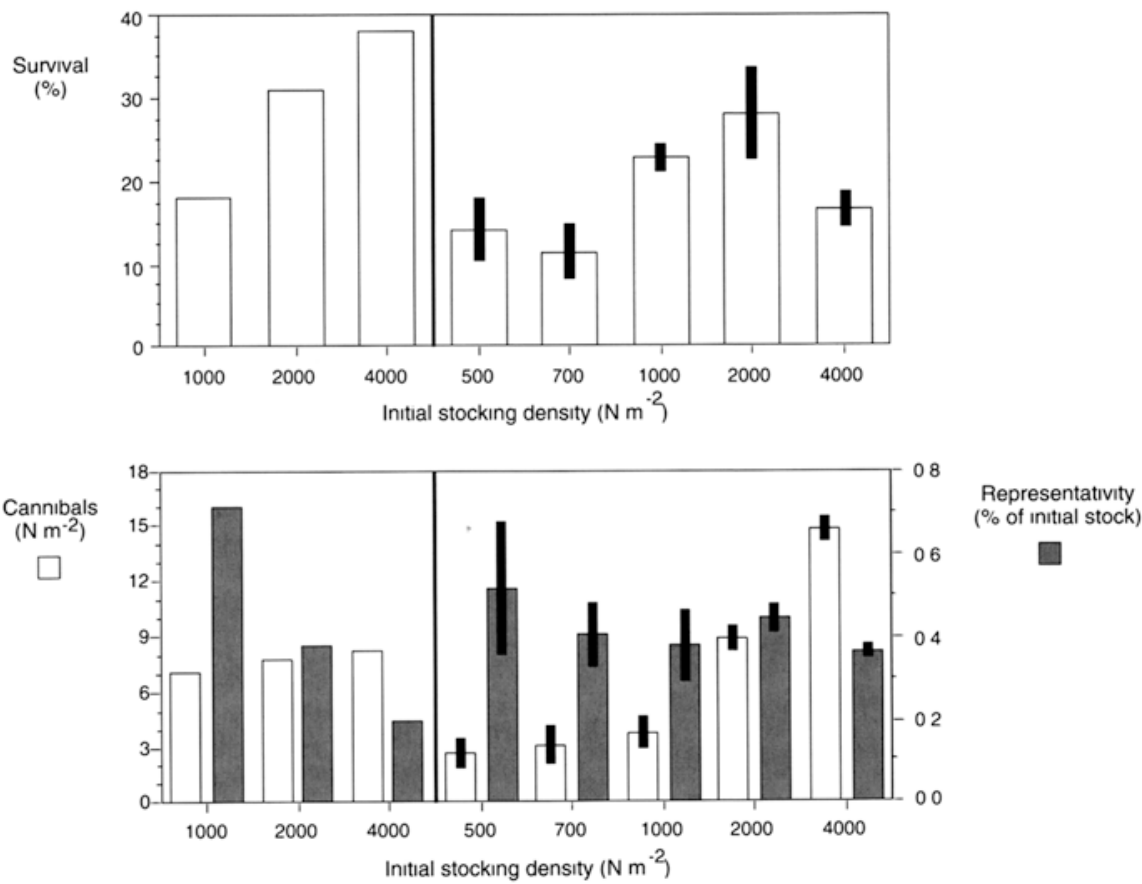

Fig. 9.9 Effect of stocking density and temperature on growth, survival and emergence of cannibalism in perch larvae reared in semi-intensive system during 45 days (From Mélard et al. (1996))

ited, resulting in a possible shortage of prey/larvae at initial densities higher than 4,000 larvae $\mathrm{m}^{-2}$.

Increased initial density of rotifers (expressed as the number of rotifers fish ${ }^{-1}$ ) improves the fish survival rate and markedly reduces cannibalism but negatively affects the growth rate of Eurasian perch larvae. The early weaning of perch reared under a restricted ration of rotifers but trained to ingest formulated dry food earlier probably explains this inverse relationship between rotifer availability and growth of larvae. 


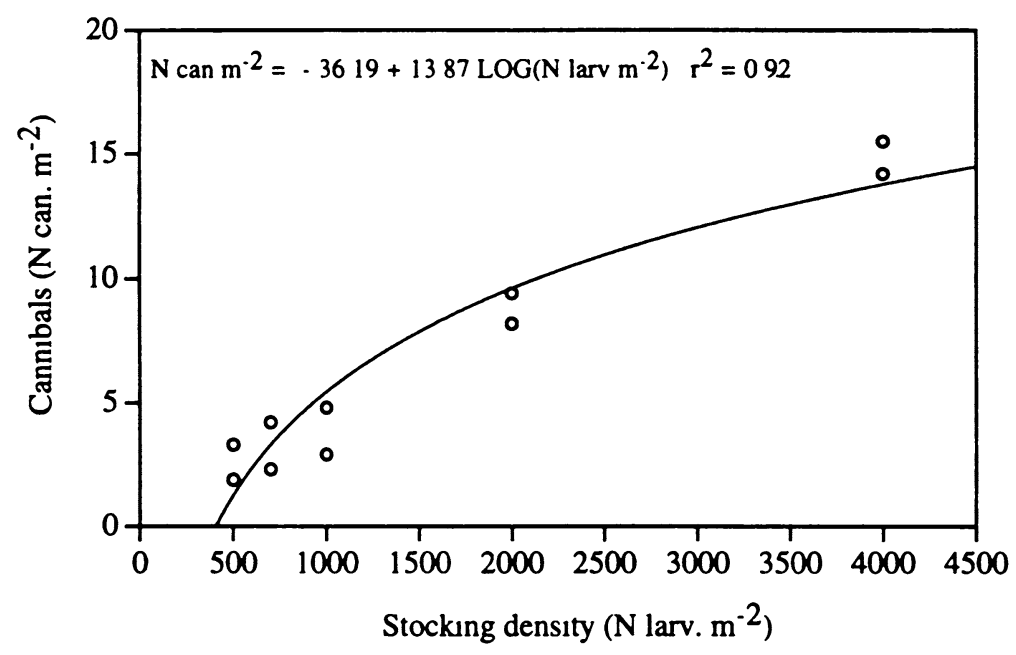

Fig. 9.10 Relationship between initial stocking density and cannibal frequency in perch larvae reared in semi-intensive system during 45 days (temperature $23^{\circ} \mathrm{C}$ ) (From Kestemont et al. (1996))

Table 9.2 Cannibalism, growth and survival rate of perch larvae reared during 44 days in mesocosm $\left(10 \mathrm{~m}^{2}\right)$ tank at 17,20 and $23{ }^{\circ} \mathrm{C}$. Initial weight: $0.9 \mathrm{mg}$. Initial stocking density: 4,000 larvae $\mathrm{m}^{-2}$ (From Mélard et al. (1996b))

\begin{tabular}{l|l|l|l}
\hline Temperature $\left({ }^{\circ} \mathrm{C}\right)$ & 17 & 20 & 23 \\
\hline Mean final weight $(\mathrm{mg}, \pm \mathrm{SD})$ & $195 \pm 49.3$ & $336 \pm 107.3$ & $607 \pm 212.3$ \\
\hline Growth $\left(\mathrm{mg} \mathrm{fish}^{-1} \mathrm{~d}^{-1}\right)$ & 4.4 & 7.6 & 13.8 \\
\hline Specific growth rate $\left(\% \mathrm{~d}^{-1}\right)$ & 12.22 & 13.46 & 14.80 \\
\hline Coefficient of variation $(\%)$ & 33 & 40 & 42 \\
\hline Survival $(\%)$ & 32.4 & 13.9 & 6.3 \\
\hline Cannibal fish $\left(\right.$ final $\left.\mathrm{N} \mathrm{m}^{-2}\right)$ & 0.7 & 6.3 & 8.6 \\
\hline Cannibal fish $(\%$ final population) & 0.05 & 1.30 & 3.50 \\
\hline
\end{tabular}

Rearing at lower temperature also limits the emergence of cannibalism during the larval stage: the ratio of cannibals decreases from $3.50 \%$ of the final population at $23{ }^{\circ} \mathrm{C}$ to $0.05 \%$ at $17{ }^{\circ} \mathrm{C}$ (Table 9.2). Consequently, survival is significantly higher at $17{ }^{\circ} \mathrm{C}$ but growth rate is $70 \%$ lower than at $23{ }^{\circ} \mathrm{C}$ (Table 9.2). More frequent pathologies, mainly parasites (Grignard et al. 1996), also induce higher mortality at $23^{\circ} \mathrm{C}$.

\subsection{Intensive Culture in Recirculating Systems}

As stressed by Kestemont and Mélard (2000), intensive culture of fry has many advantages (e.g. fairly stable culture conditions, rearing of fry produced by offseason spawning, more predictable production of juveniles and easier control of 
cannibalism) compared with extensive production in ponds or semi-intensive methods in mesocosms. However, there are several critical factors affecting the success of perch intensive culture including: poor knowledge of fish nutritional requirements, clinging and non-feeding behaviors, non-inflation of the gas bladder and cannibalism. The small mouth gape of larvae at hatching, particularly in yellow perch, and their dependence on live feed organisms have also been considered as limiting factors in intensive fry culture. Despite highly variable and sometimes unsatisfactory survival rates, a new generation of high quality artificial feeds, formulated for marine fish species, has made the problem of starter feeding a concern of low priority. Co-feeding (combining rotifers and/or Artemia nauplii as live preys and dry feed, either concurrently or successively) is still largely used in commercial Eurasian and yellow perch hatcheries, but feeding newly-hatched larvae with artificial dry feed is also feasible. Feeding and nutritional aspects of Eurasian and yellow perch early life stages are not developed in this chapter as more details are provided in Chaps. 20 and 21.

The system developed at the Ohio State University (Wojno et al. 2012) for rearing yellow perch larvae-juveniles (10-14 days) includes conical tanks with upwelling water and sprinklers designed to break surface tension (Fig. 9.11). Tanks are continuously provided with algal suspension (Instant Algae Premium 3,000, Reed Mariculture, Campbell, CA) to create turbidity of 10-14 NTU. Larvae are stocked at the density of 20-100 per L and feeding is initiated $2-3$ days after hatching at $20-25{ }^{\circ} \mathrm{C}$. The first

Fig. 9.11 Conical tanks (70 L) with central outlet, sprinkler for water tension break up and continuous supply of algae suspension to achieve turbidity of 10-14 NTU

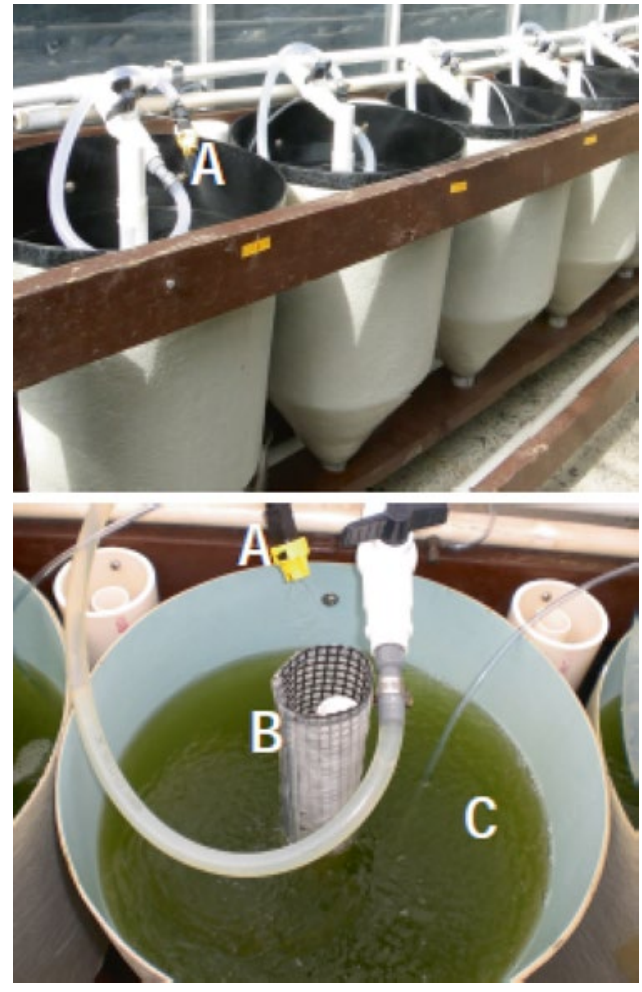


food constitutes live rotifers (3-4 days) followed by 1-2 day transition to live brine shrimp. In the successful rearing conditions, yellow perch larvae were provided with 30 rotifers $\mathrm{mL}^{-1}$ as early as 2 days after hatching. This was followed with Artemia feeding (4 nauplii $\mathrm{mL}^{-1}$ ) 1-2 days after receiving rotifers. After 10-13 days in the intensive culture system, provided exclusively with live food, larvae were weaned to dry feeds. The second phase of experiments was carried out in larger tanks to wean from live food to dry-formulated feeds. Larvae cultured under $24 \mathrm{~h}$ light conditions had significantly decreased swim bladder inflation $(39.6 \pm 8.3 \%)$ compared to those that had 12L:12D photoperiod $(60.7 \pm 14.5 \%)$. The $24 \mathrm{~h}$ light, however, had no effect on the survival (59\% versus $54 \%)$ and growth $(12.0 \pm 1.3$ versus $11.5 \pm 1.5 \mathrm{~mm}$ body length). The experiment showed no effect of the sprinkler angle on swim bladder inflation or the survival. No effect was shown when sprinklers alone or together with oil-absorbing pads were used. Body lengths after 13 days of rearing in intensive conditions were influenced by the origin of broodstock fish and amounted to $11.5 \pm 1.7$, $10.2 \pm 0.4$ and $9.0 \pm 0.5 \mathrm{~mm}$ for progenies from three different females. Furthermore, this study suggested that survival of larvae can also be affected by the origin of females: wild $(20 \%)$ or domesticated $(80 \%)$.

\subsubsection{Size Heterogeneity and Cannibalism}

As reviewed by Kestemont et al. (2003), fish of both marine and freshwater origins generally produce sibling eggs and newly hatched larvae of very similar size, with a coefficient of variation in weight (calculated as $100 \mathrm{SD}_{\text {weight }} / \mathrm{mean}_{\text {weight }}$ ) ranging between $7.5 \%$ in salmonids to $15-20 \%$ in European seabass. Coefficients of variation in weight of Eurasian perch and yellow perch are within this range (15-18\% and 8-10 \%, respectively, Kestemont et al. 1996; Kestemont and Mélard 2000). As in other percomorphs, a substantial proportion of percid fish larvae (e.g. 30-40\% in Eurasian perch) are unable to prey on Artemia nauplii, inducing an early mortality in starved larvae. Beyond day 11, cannibalism contributes to eliminating the few remaining individuals weakened by starvation (Baras et al. 2003). Braband (1995) reported that Eurasian perch consumed sibling tail first or head first. Cuff (1980) described the type I cannibalism as a prey capture tail first. The prey is swallowed progressively up to the head, which is eventually discarded. As size heterogeneity develops, cannibals switch to complete (type II) cannibalism, capture the prey head first and swallow them completely. According to Baras et al. (2003), type I cannibalism (which has a relatively low impact on overall survival) is exerted by Eurasian perch from day 11 onwards, and ceases around day 16-18 post-hatching, while the appearance of type II cannibalism (inducing up to $50 \%$ of total mortality) is determined by gape-size limitations and occurs from days 12 to 14 post-hatching. Type II cannibalism can be mitigated by size-sorting or other methods of limiting size heterogeneity.

Huston and DeAngelis (1987) suggested that changes in size distribution results from the interaction of four primary factors related to characteristics of individuals 
composing the population: initial sizes, distribution of growth rates due to differences among individuals, size and time dependence of each individual's growth rate and mortality that may affect size classes differently. In an attempt to classify the biological mechanisms producing bimodality within monospecific populations, Kestemont et al. (2003) adapted this four-class ranking proposed by Huston and DeAngelis (1987) by classifying all mechanisms as inherent (i.e. having a strong genetic component) or imposed (requiring certain biotic or abiotic conditions to be manifested). Both inherent (e.g. genetic variation, changes in morpho-physiology of larvae) and imposed mechanisms (temporal and spatial heterogeneity, competition, density-dependent or independent mortality), may or may not require interactions between individuals to be expressed.

Consequences of size heterogeneity at the early life stages are usually more dramatic than at the juvenile or adult stages, principally because larvae have a large mouth relative to body size, and they can exert cannibalism on prey (here their siblings) that are just slightly smaller (Baras 1998). Cannibalism generally requires a size difference between the potential cannibal and the victim, and is thus facilitated by size heterogeneity (Claessen et al. 2000), but it also affects size heterogeneity, since the smallest fish are consumed by the largest ones. As stressed by many authors, cannibalism in wild as well as culture environments can thus be viewed as a cause or consequence of size heterogeneity (DeAngelis et al. 1979; Hecht and Appelbaum 1988; Baras 1998).

The respective importance of several intrinsic and extrinsic factors behind growth depensation (i.e. the increase of size heterogeneity over time) and size heterogeneity was investigated within a large multi-factorial study conducted in the framework of a European project to determine the biological bases for minimizing fish competition and cannibalism in Eurasian perch larvae and post-larvae (Kestemont et al. 2003). The larval stage was defined as the period from hatching to weaning on dry feed, while the post-larvae referred to the post-weaning period (from $50 \mathrm{mg}$ to several hundred $\mathrm{mg}$ ), assuming that the fish have acquired an adult mode of digestion (see Chap. 8 for complete description of digestive system during early life stages) . The effects of different variables, grouped into three main categories (population, abiotic environment and feeding variables) were analyzed in terms of final size variation and growth, survival and cannibalism. Table 9.3 summarizes the main significant outputs of this study.

Among the population variables, hatching time and stocking density significantly impacted on the population dynamics of Eurasian perch. Within a cohort, earlier hatch resulted in higher survival and faster growth. This was observed both in mixed groups (larvae hatched on D1 +D2 were labeled in alizarin red solution to be distinguished from larvae hatched later) and when fish hatching at different times were reared separately. Obviously, fish hatching earlier have greater competitive capabilities; they gain access to food earlier, grow faster and can eventually exhibit cannibalistic behavior on their younger siblings. Different hatching times within a single batch of eggs can also reflect different quality of eggs, and consequently different quality of larvae (Kestemont et al. 2003). The effects of stocking density on rearing performance differed between perch larvae and post-larvae. At the larval stage, the slowest growth and higher rates of 
Table 9.3 Population, environment and feeding variables significantly affecting the final size variation, growth ${ }^{\mathrm{a}}$, survival and/or cannibalism in Eurasian perch larvae and post-larvae reared in tanks (Data compiled from (Kestemont et al. 2000, 2003; Baras et al. 2003))

\begin{tabular}{|c|c|c|c|c|c|c|c|}
\hline Variables & Stage & Tested levels & $\begin{array}{l}\text { Initial } \\
\text { mass } \\
(\mathrm{mg})\end{array}$ & $\begin{array}{l}\text { Final } \\
\text { mass } \\
(\mathrm{mg})\end{array}$ & $\begin{array}{l}\mathrm{CV}_{\text {weight }} \\
(\%)\end{array}$ & $\begin{array}{l}\text { Survival } \\
(\%)\end{array}$ & $\begin{array}{l}\text { Cannibalism } \\
(\%)\end{array}$ \\
\hline \multicolumn{8}{|c|}{ Population variables } \\
\hline \multirow[t]{3}{*}{ Hatching time } & \multirow[t]{3}{*}{ Larvae } & $\mathrm{D} 1+\mathrm{D} 2^{\mathrm{b}}$ & 0.8 & $84.7^{\mathrm{a}}$ & 30.9 & $62.2^{\mathrm{a}}$ & 10.7 \\
\hline & & D3 ${ }^{\mathrm{b}}$ & & $59.1^{\mathrm{b}}$ & 53.5 & $39.0^{\mathrm{b}}$ & 3.97 \\
\hline & & D1-D3 ${ }^{b}$ & & $59.4^{\mathrm{b}}$ & 46.9 & $30.0^{\mathrm{b}}$ & 6.56 \\
\hline \multirow{6}{*}{$\begin{array}{l}\text { Initial size } \\
\text { heterogeneity }\end{array}$} & \multirow[t]{3}{*}{ Larvae } & Standard ${ }^{\mathrm{c}}$ & 8.60 & 121 & 29.7 & 47.3 & 8.70 \\
\hline & & $\mathrm{High}^{\mathrm{c}}$ & & 155 & 40.0 & 56.0 & 11.9 \\
\hline & & Controlled $^{\mathrm{c}}$ & & 144 & 40.3 & 47.2 & 20.6 \\
\hline & \multirow{3}{*}{$\begin{array}{l}\text { Post- } \\
\text { larvae }\end{array}$} & Standard ${ }^{c}$ & 84.4 & 442 & 35.3 & 54.5 & $2.2^{\mathrm{a}}$ \\
\hline & & $\mathrm{High}^{\mathrm{c}}$ & & 500 & 38.1 & 36.2 & $19.8^{\mathrm{b}}$ \\
\hline & & Controlled $^{\mathrm{c}}$ & & 280 & 35.9 & 42.9 & $16.4^{\mathrm{b}}$ \\
\hline \multirow{6}{*}{$\begin{array}{l}\text { Stocking } \\
\text { density }\end{array}$} & \multirow[t]{3}{*}{ Larvae } & 10 fish $\mathrm{L}^{-1}$ & 1.04 & $7.3^{\mathrm{a}}$ & 46.2 & 14.7 & $54.6^{\mathrm{a}}$ \\
\hline & & $32{\text { fish } L^{-1}}$ & & $9.7^{\mathrm{b}}$ & 43.1 & 18.9 & $29.6^{\mathrm{b}}$ \\
\hline & & 100 fish $\mathrm{L}^{-1}$ & & $11.2^{\mathrm{c}}$ & 36.1 & 20.1 & $35.7^{\mathrm{a}, \mathrm{b}}$ \\
\hline & \multirow{3}{*}{$\begin{array}{l}\text { Post- } \\
\text { larvae }\end{array}$} & 1 fish $L^{-1}$ & 188 & $816^{\mathrm{a}}$ & 27.2 & $97.3^{\mathrm{a}}$ & $0^{\mathrm{a}}$ \\
\hline & & $3.2{\text { fish } \mathrm{L}^{-1}}$ & & $932^{\mathrm{b}}$ & 31.4 & $95.8^{\mathrm{a}}$ & $0.3^{\mathrm{a}}$ \\
\hline & & 10 fish $\mathrm{L}^{-1}$ & & $865^{\mathrm{a}, \mathrm{b}}$ & 32.5 & $75.3^{\mathrm{b}}$ & $21.1^{\mathrm{b}}$ \\
\hline \multicolumn{8}{|c|}{ Environmental variables } \\
\hline \multirow[t]{8}{*}{ Day length } & \multirow[t]{4}{*}{ Larvae } & LD $8: 16$ & 1.04 & $21.7^{\mathrm{a}}$ & $43.4^{\mathrm{a}}$ & $39.6^{\mathrm{a}}$ & 19.8 \\
\hline & & LD 12:12 & & $68.3^{\mathrm{b}}$ & $34.8^{\mathrm{a}, \mathrm{b}}$ & $45^{\mathrm{a}, \mathrm{b}}$ & 18.7 \\
\hline & & LD16:8 & & $62.2^{\mathrm{b}}$ & $24.0^{\mathrm{c}}$ & $49^{\mathrm{a}, \mathrm{b}}$ & 21.8 \\
\hline & & LD 24:0 & & $67.8^{\mathrm{b}}$ & $25.0^{\mathrm{b}, \mathrm{c}}$ & $56.2^{\mathrm{b}}$ & 25.0 \\
\hline & \multirow{4}{*}{$\begin{array}{l}\text { Post- } \\
\text { larvae }\end{array}$} & LD 8:16 & 83.8 & 290 & 28 & 93.2 & $10.2^{\mathrm{a}}$ \\
\hline & & LD 12:12 & & 296 & 24.3 & 87.0 & $7.7^{\mathrm{a}}$ \\
\hline & & LD16:8 & & 313 & 29.5 & 90.7 & $4.0^{\mathrm{a}}$ \\
\hline & & LD 24:0 & & 280 & 24.7 & 88 & $0.4^{\mathrm{b}}$ \\
\hline \multirow[t]{8}{*}{ Light intensity } & \multirow[t]{4}{*}{ Larvae } & $5 \operatorname{Lux}$ & 1.04 & $58.7^{\mathrm{a}}$ & 45.6 & 44.4 & 27.5 \\
\hline & & $30 \operatorname{Lux}$ & & $90.0^{\mathrm{a}, \mathrm{b}}$ & 48.3 & 47.7 & 39.6 \\
\hline & & $90 \operatorname{Lux}$ & & $88.5^{\mathrm{a}, \mathrm{b}}$ & 38.1 & 53.3 & 19.9 \\
\hline & & 400 Lux & & $112^{\mathrm{b}}$ & 36.6 & 52.7 & 25.1 \\
\hline & \multirow{4}{*}{$\begin{array}{l}\text { Post- } \\
\text { larvae }\end{array}$} & $5 \operatorname{Lux}$ & 45.9 & $408^{a}$ & 30.3 & 73.3 & 22.3 \\
\hline & & 30 Lux & & $324^{\mathrm{a}, \mathrm{b}}$ & 39.1 & 74.8 & 11.4 \\
\hline & & 90 Lux & & $290^{\mathrm{b}, \mathrm{c}}$ & 30.5 & 67.8 & 15.5 \\
\hline & & 400 Lux & & $219^{c}$ & 34.2 & 69.9 & 19.2 \\
\hline \multicolumn{8}{|c|}{ Feeding variables } \\
\hline Feeding level & Larvae & 1 & 8.6 & $12^{\mathrm{a}}$ & 33 & $30^{\mathrm{a}}$ & 5.8 \\
\hline \multirow{3}{*}{$\begin{array}{l}\text { (\% biomass } \\
\left.\text { day }^{-1}\right)\end{array}$} & & 5 & & $15^{\mathrm{a}}$ & 42 & $78^{\mathrm{b}}$ & 6.2 \\
\hline & & 10 & & $39^{\mathrm{b}}$ & 39 & $78^{\mathrm{b}}$ & 10 \\
\hline & & 20 & & $52^{c}$ & 55 & $67^{\mathrm{b}}$ & 8 \\
\hline
\end{tabular}

Values with different superscripts within a same column are significantly different $(p<0.05)$

${ }^{a}$ Mass values refer to non-cannibal fish

${ }^{\mathrm{b}} \mathrm{D} 1+\mathrm{D} 2=$ larvae hatched during the first 2 days of the hatching period; $\mathrm{D} 3=$ larvae hatched on day 3; D1-D3 = larvae hatched on days 1-3

'Standard size heterogeneity = sibling fish reared in the same tank from hatching under standard conditions, high = sibling fish initially reared at two different stocking densities to create size differences, then mixed altogether; controlled = sibling fish with regular size-sorting (i.e. removal of both large and small individuals) 
cannibalism were observed at low stocking density and can be attributed to several factors, such as the development of dominance hierarchies, growth depensation and territoriality. Baras et al. (2003) described a shoaling behavior of larvae held at intermediate and high stocking density while fish reared at low density were dispersed. At high stocking density the number of available territories is proportionally limited, as is the number of cannibals, explaining why the cannibalism was less intense at the highest density. The number of fish classified as cannibals at the end of the experiment was proportional to stocking density, but the proportion of cannibals relative to the initial number of fish was negatively correlated to stocking density (Baras et al. 2003). Similar observations were made by Mélard et al. (1996) in large-scale experiments conducted in mesocosms (see also Sect. 9.3). At the post-larval stage, unlike the larval stage, Eurasian perch were negatively affected by high stocking density, which induced slow growth and high rates of cannibalism. A density-dependent variation in food availability was suggested to explain these results; all fish reared at low and intermediate stocking density having access to food, while not at the highest density. Surprisingly, initial size heterogeneity had very little influence on final size heterogeneity and cannibalism in both larvae and post larvae of Eurasian perch while this factor is frequently invoked as a key to cannibalism and growth depensation in many other species, including the walleye Sander vitreum (Loadman et al. 1986). In Eurasian perch, the frequent removal of larger, supposedly cannibalistic individuals did not improve survival or growth, probably because their removal promoted the rapid establishment of new dominance hierarchies and resulted in more frequent agonistic interactions between fish. Therefore, the usefulness of size-sorting practices at the larval stage is highly questionable, except for the initial sorting based on hatching time. The same statement was made by Babiak et al. (2004) when investigating the effects of initial weight and its variation on quantitative characteristics of juvenile cohorts in Eurasian perch larvae. Despite considerable differences in initial CV of different Eurasian perch progenies (CV: $219 \%$ versus $34.5 \%$ and $56 \%$ at $7 \mathrm{mg}$ initial body weight), intermediate and final CVs of weight were stable at $30-40 \%$ (for fish of 2-5 g final body weight) regardless of progenies and growth characteristics (Babiak et al. 2004).

Rearing temperature is probably among the main environmental variables susceptible to influence the size heterogeneity and, consequently, the cannibalism rate, as it governs the fish growth rate, and thus may induce growth depensation. Since a temperature of $20-23^{\circ} \mathrm{C}$ is usually recommended as optimal for the intensive larval culture of Eurasian perch, there are few data available on the effects of low or high temperature on growth, size heterogeneity and cannibalism in fish reared in recirculating systems. Kestemont and Mélard (2000) reported that temperature significantly influences the specific growth rate (SGR) of Eurasian perch larvae (from 16.4 to $118 \mathrm{mg}$ body mass), with a maximum of $22.0 \%$ day $^{-1}$ at $23{ }^{\circ} \mathrm{C}$ when fish were fed high daily rations ( $35 \%$ body mass per day) while, at 14 and $26^{\circ} \mathrm{C}$, the SGR did not exceed 11 and $15 \%$ day $^{-1}$, respectively (see also Sect. 9.3).

As shown in Table 3.1, survival, growth and size homogeneity among larvae were improved in Eurasian perch when day length was increased. Percid fish larvae are visual feeders, exhibiting a stronger feeding behavior in light than in darkness. Moreover, the increased and well distributed number of meals under long day length or continuous lighting might have enhanced larval food access, reducing growth 
depensation and, as a corollary, the incidence of cannibalism. An alternative explanation may be that potential cannibals can forage over longer periods of time thus reducing their tendency for cannibalistic activity (Kestemont et al. 2003). It is likely that increased day length impacts the behavior of both potential cannibals and potential prey. At the post-larval stage, day length did not significantly influence the survival of Eurasian perch but the proportion of mortality due to cannibalism was significantly reduced when day length was increased from LD 8:16 to LD 24:0.

Feed supply greatly affects the establishment of dominance hierarchies, growth depensation and cannibalism (Paller and Lewis 1987; Hecht and Pienaar 1993). Even in species rarely displaying cannibalistic behavior such as the goldfish Carassius auratus, cannibalism occurs frequently among larvae when they are poorly fed or starved (Kestemont 1995). However in Eurasian perch, cannibalism was higher at an intermediate ration when compared to low or high rations. If high feeding level has limited the impact of cannibalism, low ration has impaired the growth rate of all fish, postponing the cannibalism until some fish reached the minimum size to exert their cannibalistic behavior.

\subsubsection{Clinging, Non-feeding Behavior and Non-inflation of the Gas Bladder}

In nature, the presence of suspended matter (phytoplankton, clay, etc.) is responsible for rather high turbidity, limiting the light penetration into water. In tanks, water turbidity is low (usually below $5 \mathrm{NTU}$ ), light passes through the water and is reflected from tank surfaces. The term "clinging behavior" has been initially used by Summerfelt (1996) for describing the attraction of larval walleyes to these tank surfaces. This behavior is usually associated with the refusal of feed intake, regardless of the type of feed supplied (live prey or artificial feed). Clinging and associated non-feeding behaviors are also quite common in Eurasian perch and yellow perch when newly-hatched larvae are stocked in tanks of small sizes, while these behaviors are rarely observed in large tanks. Once feed intake is initiated, the larvae continue to ingest feed regardless of tank size, and the clinging and non-feeding behaviors disappear. The addition of clay to make the water turbid (up to $50 \mathrm{NTU}$ ) and to increase light diffusion has been recommended for walleye larvae by Bristow and Summerfelt (1994). Algae suspension was successfully applied to yellow perch and in this case the turbidity was in the range of 10-15 NTU during the first 10-12 days of rearing (Kwasek et al. 2013). Fish were then transferred to tanks without turbidity for further rearing. The combination of light intensity and tank color also modifies the efficiency of food perception and the feeding behavior of perch larvae. Hinshaw (1986) suggested that yellow perch larvae were attracted by the white walls and ceased feeding while dark wall tanks facilitated prey detection by improving the contrast between the food and the walls. The use of grey walls and a diffuse light source is thus appropriate (Hinshaw 1985). Similar results were obtained for European perch where black tank walls resulted in improved body weight and condition factor in comparison to groups reared in tanks with gray walls (Tamazouzt 1995; Jentoft et al. 2006). However, results of these experiments are 
of limited value as all treatments averaged $75 \%$ mortality. Tamazouzt et al. (2000) recommended the use of white or light colored walls for the larval culture of Eurasian perch under a maximum light source of 800 lux at the water surface in the case of fish being reared with inert prey (frozen zooplankton and formulated dry feeds). Kestemont et al. $(2003,2008)$ reported the highest growth and survival rates with a light intensity of 90-400 lux and a long day length (LD 16:8 or 24:0) if a continuous feed supply is ensured. Most recent data suggest that yellow perch tolerate a wide range of light intensity, whereas prey density ( 25 vs. 150 zooplankton $\mathrm{L}^{-1}$ ) has a significant impact on growth and survival (Martin et al. 2012). Eurasian perch can feed to certain extent in complete darkness using lateral line perception if food density is high (Dabrowski 1982). A less explored area of visual feeding in perch larvae is the spectral characteristic of the light employed for culture (Loew et al. 1993). Yellow perch juveniles (length 25-32 mm) have the highest relative quantal sensitivity at $360 \mathrm{~nm}$, near ultraviolet wavelength, although the number of UV-sensitive cones in their retina, like in other teleosts, decreases dramatically in comparison to larval stages. Visual perception based on near ultraviolet and UV-A and UV-B vision (320-360 nm) must also take into account detrimental effect of UV-A light intensity as demonstrated in yellow perch larvae subjected to this short wavelength (Boily et al. 2011).

Non-inflation of gas bladder (NIGB) has been described in the wild in European lakes (Egloff 1996) as well in N. American Lake Michgan (Czesny et al. 2005). The latter authors demonstrated that the frequency of non-inflation in yellow perch was between $5 \%$ and $25 \%$. The affected fish were in the size range of 10-15 mm. only those with filled swim bladders survive to a size larger than $20 \mathrm{~mm}$. This is not the case in intensive systems with available food where individuals with uninflated swim bladder were observed.

Eurasian perch and yellow perch are species that are much more sensitive to an increase surface tension than walleye and pikeperch (Colesante et al. 1986; Barrows et al. 1988; Summerfelt 1996), most likely due to their smaller size at the time of swim bladder inflation (6-8 mm total body length). As recommended for these latter species, spray flow, avoiding the accumulation of an oil film at the water surface, can be used successfully to reduce the risk of NGIB and, consequently, the rate of skeletal deformities (pre-haemal lordosis and/or scoliosis). Equipment such as surface skimmers and degassers may also be employed but were not specifically tested with walleye or yellow perch. As described for pikeperch and walleye in Chap. 10 and 11, fish without inflated gas bladders will survive in aquaculture systems but more energy will be devoted to swimming activities, and this re-allocation of energy will be done at the detriment of growth (Ostaszewska 2005).

Furthermore, Jacquemond (2004) described the phenomenon of late swim bladder inflation (up to $66 \%$ of the fish population) in Eurasian perch and argued that fish recovered completely at the size of 68-72 $\mathrm{mm}$ body length. We tested this assumption in yellow perch (Fig. 9.12) using the same method of separation of inflated and non-inflated swim bladder fish with anesthesia. We validated our method with X-ray analysis at the time of separation. We found no evidence of late swim bladder inflation in yellow perch and although fish continue to grow, the growth rate of non-inflated perch was inferior in comparison to control and severe skeletal deformities were observed. 


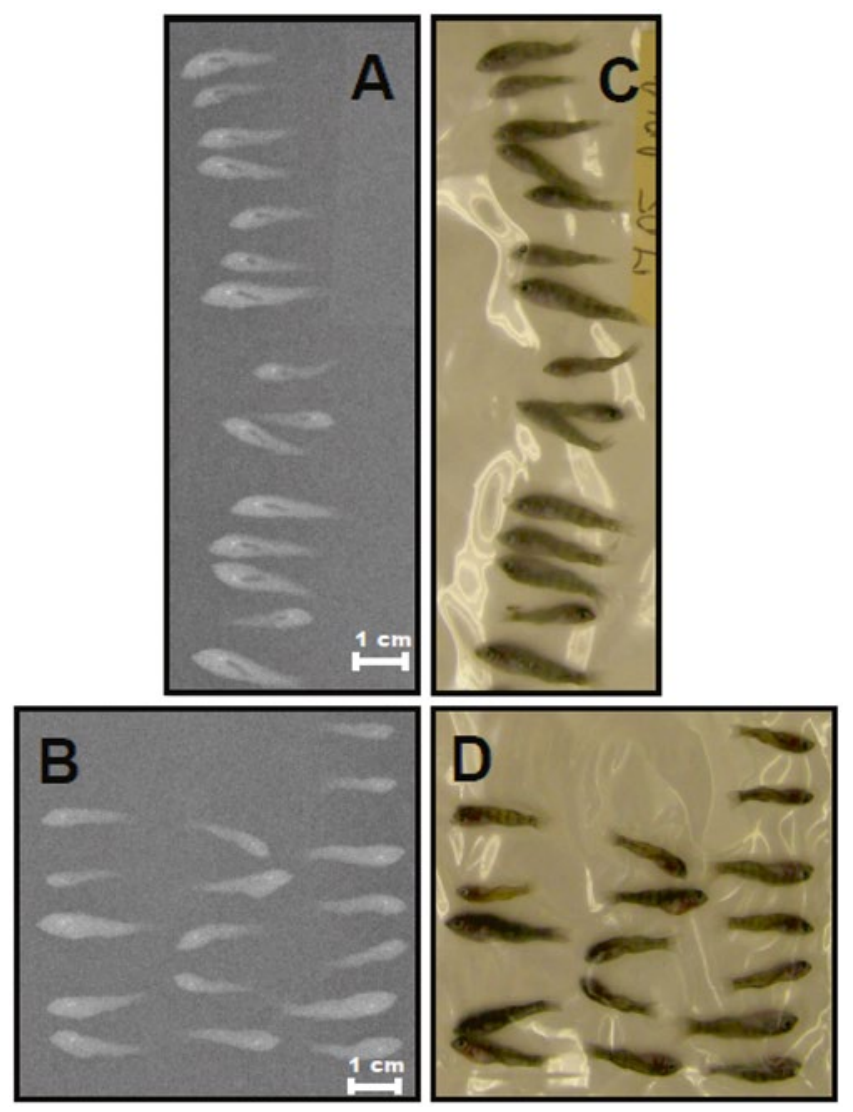

Fig. 9.12 X-ray and direct images of larval and juvenile yellow perch $(0.01-0.1 \mathrm{~g})$ with inflated $(\mathbf{a}, \mathbf{c})$ and un-inflated $(\mathbf{b}, \mathbf{d})$ swim bladder

\subsubsection{Culture Tanks and Larval Rearing Conditions in Semi-commercial Conditions}

Intensive culture of Eurasian and yellow perch larvae is usually performed in recirculating aquaculture system(s) (RAS) in order to efficiently control water quality and to avoid or reduce the presence of pathogens. Larval rearing tanks are of various shapes and materials, squared or cylindro-conical, or made of cages (with 250$300 \mu \mathrm{m}$ mesh size) placed in large concrete tanks. Regardless of shape, they must be rather large, ranging from $300 \mathrm{~L}$ to several $\mathrm{m}^{3}$, to avoid the clinging and non-feeding behaviors described above. As said before, dark walls or increased turbidity are recommended for facilitating the detection of feed and avoidance of cannibalism by the juveniles of $12-15 \mathrm{~mm}$. At hatching, Eurasian perch and yellow perch are rather fragile and sensitive to handling. Transfer of perch at the eyed egg stage is thus recommended to reduce the mortalities induced by manipulation. Eggs can be suspended on trays about 1 day before hatching, initially at a temperature close to that 
of incubation $\left(17-18{ }^{\circ} \mathrm{C}\right)$. Within 1 day temperature is raised to $20{ }^{\circ} \mathrm{C}$, and then maintained constant between 20 and $23{ }^{\circ} \mathrm{C}$, depending on strains, throughout the larval rearing phase, up to the time of transfer of juveniles to grow-out tanks (Kestemont et al. 1996, 2008).

Initial stocking density ranges between 20 and 50 larvae $\mathrm{L}^{-1}$. Higher densities, up to 100 newly hatched larvae $\mathrm{L}^{-1}$ have been successful, but fish density must be reduced after the weaning phase, as the fish grow (Kestemont et al. 2008).

Feeding starts 2-3 days post-hatching (dph), usually with small strains of Artemia nauplii (350-380 $\mu \mathrm{m}$ ) during few days and then with regular size Artemia nauplii $(420-450 \mu \mathrm{m})$. During the first week, a daily ration of 500-1,000 nauplii per larvae is provided, distributed very frequently by hand or with a peristaltic pump during the daylight period. From the end of the first week to the end of week 3 , the daily ration, calculated on the dry matter basis of Artemia, can be reduced from $35 \%$ to $10 \%$ of fish biomass. On day 21 post-hatching, when fish have a mean body mass of $50 \mathrm{mg}$, they can be trained to accept dry feed, by replacing progressively the live prey with a high quality compound feed $(300-500 \mu \mathrm{m})$ within 4 days (Kestemont and Mélard 2000; Kestemont et al. 2008). Recently, fish feed companies have developed high quality dry diets enriched in phospholipids as unique starter feed, supporting satisfactory survival and growth rates, together with low skeletal deformities, similar to the results obtained with live feed. A detailed description of feeding and nutrition requirements of Eurasian perch and yellow perch is provided in Chaps. 20 and 21, respectively.

\subsubsection{Production Data}

In Eurasian perch, larval stocking densities ranging from 20 to 100 fish $\mathrm{L}^{-1}$ have been tested under commercial conditions in a hatchery using a RAS technology until day 49 post-hatching. Fish were maintained in triplicate in 500-L squared polyester tanks at a temperature of $21-22{ }^{\circ} \mathrm{C}$ and LD 12:12 (50 lux at water surface). They were fed eight times a day with Artemia nauplii from day 3 to day 21, followed by a progressive habituation to dry feed (co-feeding) during 10 days, and then exclusively dry diet. Growth curves were rather similar in all treatments $\left(\mathrm{SGR}=13-14 \% \mathrm{~d}^{-1}\right)$, and fish body weight reached between 0.59 and $0.71 \mathrm{~g}$. Final biomass was significantly influenced by the initial stocking density, ranging from $5.8 \mathrm{~kg} \mathrm{~m}^{-3}$ at the low initial density to $35.4 \mathrm{~kg} \mathrm{~m}^{-3}$ at the highest one (Fontaine et al. 2001). Similar results with a final biomass of $35 \mathrm{~kg} \mathrm{~m}^{-3}$ at the end of the nursery phase are reported by different French and Swiss producers of Eurasian perch (P. Fontaine and T. Janssen, pers. com.). Higher stocking density, up to 150 fish $\mathrm{L}^{-1}$, is practiced in Ireland where fish are weaned to dry diet from day 16 onwards (D. Toner, pers. com.). Depending on fish farms, survival rates of Eurasian perch vary between hatch and the end of the nursery cycle, but usually range between $15 \%$ and $35 \%$ within $3-4$ months, from larval stage to $5 \mathrm{~g}$ juvenile. In Irish nursery farms, a survival rate of up to $50 \%$ is a consistent result, but some $25 \%$ of these fish are culled during ongrowing because of slow growth (D. Toner, pers. com.). 


\subsection{Conclusions}

While significant progress in the rearing of early life stages of Eurasian perch and yellow perch has been achieved during the last two decades, the cost and availability of feed trained fingerlings remains a considerable bottleneck in the production protocol for the perch food fish industry. In yellow perch the tandem pond/tank is the most widely used method for producing weaned juveniles in the USA. Large numbers of juveniles can be produced by a rather simple method, with lowered incidence of nutritional deformities. The use of this method however, requires both pond and tank facilities neither of which are employed to their maximum potential. Development of efficient and reliable intensive fry culture protocols as well as yearround availability of yellow perch eggs will have a significant impact on the expansion of the industry. In Eurasian perch, the semi-intensive rearing in small green water tanks (mesocosms) combined with daily supply of live food and dry diet also constitutes a rather simple and cheap alternative to the intensive production in tank for the production of weaned juveniles. The logistics of producing and supplying adequate levels of live prey on a commercial scale however represents additional demands on labour and facilities for success of the overall protocol. The recent availability of high quality commercial diets that were initially formulated for marine fish larvae but provided good results in percid fish species may limit the need for Artemia nauplii as starter feed and could simplify the rearing procedure. Intensive rearing of percid larvae in RAS has been extensively investigated in experimental conditions and optimal husbandry conditions are now available for both species, at least at the laboratory scale. Applications of these techniques on a commercial scale will be required to determine their efficiency and productivity. Mortalities, largely caused by cannibalism and skeletal deformities, still limit the reliability of this system, but significant improvements have been achieved by controlling the physical environment, the fish stocking density and the feeding scheme. Commercial production of Eurasian perch larvae is now operational throughout the year in several European countries and some initiatives have started recently in USA.

\section{References}

Babiak I, Mandiki SNM, Ratsinjomanana K, Kestemont P (2004) Initial weight and its variation in post-larval Eurasian perch affect quantitative characteristics of juvenile cohorts under controlled conditions. Aquaculture 243:263-276

Baras E (1998) Bases biologiques du cannibalisme chez les poissons. Cah Ethol 18:53-98

Baras E, Kestemont P, Mélard C (2003) Effect of stocking density on the dynamics of cannibalism in sibling larvae of Perca fluviatilis under controlled conditions. Aquaculture 219:241-255

Barrows FT, Lellis WA, Nickum JG (1988) Intensive culture of larval walleye with dry or formulated feed: note on swim bladder inflation. Prog Fish Cult 50:160-166

Boily V, Bertolo A, Magnan P, Martinoli M-G, Therien H-M (2011) The effect of UVR irradiance and spectral composition on yellow perch (Perca flavescens) larvae survival. Aquat Sci 73:345-354

Boyd CE (1977) Practical aspects of chemistry in pond aquaculture. Prog Fish Cult 59:85-93 
Boyd CE (2012) Nutrient cycling. In: Mischke CC (ed) Aquaculture pond fertilization: impacts of nutrient input on production. Wiley-Blackwell, Oxford, pp 3-21

Braband A (1995) Intracohort cannibalism among larval stages of perch (Perca fluviatilis). Ecol Freshw Fish 4:70-76

Bremigan MT, Dettmers JM, Mahan AL (2003) Zooplankton selectivity by larval yellow perch in Green Bay, Lake Michigan. J Great Lakes Res 29:501-510

Bristow BT, Summerfelt RC (1994) Performance of larval walleye cultured intensively in clear and turbid water. J World Aquac Soc 25:454-464

Claessen D, De Roos AM, Persson L (2000) Dwarfs and giants: cannibalism and competition in size-structured populations. Am Nat 155:219-237

Colesante RT, Youmans NB, Ziolkoski B (1986) Intensive culture of walleye fry with live food and formulated diets. Prog Fish Cult 45:126-127

Cuff WR (1980) Behavioral aspects of cannibalism in larval walleye, Stizostedion vitreum. Can J Zool 58:1504-1507

Culver DA (1996) Fertilization procedures for pond culture of walleye and saugeye. In: Summerfelt RC (ed) Walleye culture manual, vol 101, NCRAC culture series. North Central Regional Aquaculture Center Publications Office, Iowa State University, Ames, pp 115-122

Czesny SJ, Graeb BDS, Dettmers JM (2005) Ecological consequences of swim bladder non inflation for larval yellow perch. Trans Am Fish Soc 134:1011-1020

Dabrowski KR (1982) The influence of light intensity on feeding of fish larvae and fry. II. Rutilus rutilus (L.) and Perca fluviatilis (L.). Zool J Physiol 86:353-360

Dabrowski K (1984) The feeding of fish larvae. Present state of the art and perspectives. Reprod Nutr Dev 24:807-833

DeAngelis DL, Cox DK, Coutant CC (1979) Cannibalism and size dispersal in young-of-the-year largemouth bass: experiment and model. Ecol Model 8:133-148

Egloff M (1996) Failure of swim bladder inflation of perch, Perca fluviatilis L. found in natural populations. Aquat Sci 58:15-23

Fontaine P, Kestemont P, Mélard, Verstraete W (2001) New microbial technologies applied to the rearing of Eurasian perch (Perca fluviatilis) in recirculating aquaculture system. Final report FAIR CT98-9241 (1/1/99-31/12/00). Nancy, 149p

Fulford RS, Rice JA, Miller TJ, Binkowski FP, Dettmers JM, Belonger B (2006) Foraging selectivity by larval yellow perch (Perca flavescens): implications for understanding recruitment in small and large lakes. Can J Fish Aquat Sci 63:28-42

Grignard JC, Melard C, Kestemont P (1996) A preliminary study of parasites and diseases of perch in an intensive culture system. J Appl Ichthyol 12(3-4):195-199

Hart SD, Garling DL, Malison JA (eds) (2006) Yellow perch (Perca flavescens) culture guide, vol 103, NCRAC culture series. Iowa State University, Ames

Hartleb CF (2003) Food chain dynamics and diets of larval and post-larval yellow perch in culture ponds. In: Barry TP, Malison JA (eds) Proceedings of Percis III: the third international percid fish symposium. University of Wisconsin Sea Grant Institute, Madison

Hartleb CF, Johnson JA, Held JA (2012) Walleye and yellow perch pond fertilization. In: Mischke $\mathrm{CC}$ (ed) Pond fertilization: impacts of nutrient input on aquaculture production. WileyBlackwell, Oxford, pp 147-161

Hecht T, Appelbaum S (1988) Observations on intraspecific aggression and coeval sibling cannibalism by larva and juvenile Clarias gariepinus (Clariidae: Pisces) under controlled conditions. J Zool Lond 214:21-44

Hecht T, Pienaar AG (1993) A review of cannibalism and its implications in fish larviculture. J World Aquac Soc 24:246-261

Heidinger RC, Kayes TB (1986) Yellow perch. In: Stickney RR (ed) Culture of nonsalmonid freshwater fishes. CRC Press, Boca Raton, pp 103-113

Held JA, Malison JA, Kuczynski TE (1998) Techniques for the commercial production of feedtrained yellow perch (Perca flavescens) fingerlings. World Aquaculture Society book of abstracts 29th annual meeting of the World Aquaculture Society, Las Vegas 
Hinshaw JM (1985) Effects of illumination and prey contrast on survival and growth of larval yellow perch Perca flavescens. Trans Am Fish Soc 114:540-545

Hinshaw JM (1986) Factors affecting feeding, survival and growth of larval and early juvenile yellow perch (Perca flavescens Mitchill). PhD thesis, North Carolina State University, Raleigh, $80 \mathrm{p}$

Huston MA, DeAngelis DL (1987) Size bimodality in monospecific populations: a critical review of potential mechanisms. Am Nat 129:678-707

Jacob AP, Culver DA (2010) Experimental evaluation of the impacts of reduced inorganic phosphorus fertilization rates on juvenile saugeye production. Aquaculture 304:22-33

Jacquemond F (2004) Separated breeding of perch fingerlings (Perca fluviatilis L.) with and without initial inflated swim bladder: comparison of swim bladder development, skeleton conformation and growth performance. Aquaculture 239:261-273

Jentoft AH, Oxnevad S, Aastevit A, Andersen Q (2006) Effects of tank wall color and up-welling water flow on growth and survival of Eurasian perch larvae (Perca fluviatilis). J World Aquac Soc 37:313-317

Kestemont $\mathrm{P}$ (1995) Influence of feed supply, temperature and body size on the growth of goldfish Carassius auratus larvae. Aquaculture 136:341-349

Kestemont P, Mélard C (2000) Chapter 11: Aquaculture. In: Craig JF (ed) Percid fishes. Systematics, ecology and exploitation. Blackwell Science, Oxford, pp 191-224

Kestemont P, Mélard C, Fiogbé E, Vlavonou R, Masson G (1996) Nutritional and animal husbandry aspects of rearing early life stages of Eurasian perch Perca fluviatilis. J Appl Ichthyol $12: 157-165$

Kestemont P, Cuvier A, Houbart M, Mélard C, Baras E, Fontaine P, Jourdan S, Gardeur J-N, Anthouard M, Boujard T, Kentouri M, Pasapatis M, Ducarme C (2000) An integrated study of interindividual competition and its relationships with feeding physiology and behavior in cultured predatory fish. Fair CT96-1572 final report, $118 \mathrm{p}$

Kestemont P, Jourdan S, Houbart M, Mélard C, Paspatis M, Fontaine P, Cuvier A, Kentouri M, Baras E (2003) Size heterogeneity, cannibalism and competition in cultured predatory fish larvae: biotic and abiotic influences. Aquaculture 227:333-356

Kestemont P, Rougeot C, Musil J, Toner D (2008) Chapter 5: Larval and juvenile production. In: Toner D, Rougeot C (eds) Farming of Eurasian perch, vol 1. Juvenile production. Aquaculture explained, n 24. Irish Sea Fisheries Board, Dublin, pp 30-41

Kwasek K, Wojno M, Niass F, Grayson J, Dabrowski K (2013) The art of raising yellow perch in captivity. World Aqauculture Society, book of abstract, Nashville, 21-25 Feb

Loadman NL, Moodie GEE, Mathias JA (1986) Significance of cannibalism in larval walleye (Stizostedion vitreum). Can J Fish Aquat Sci 43:613-618

Loew ER, McFarland WN, Mills EL, Hunter D (1993) A chromatic action spectrum for planktonic predation by juvenile yellow perch, Perca flavescens. Can J Zool 71:384-386

Malison JA, Held JA (1992) Effects of fish size at harvest, initial stocking density and tank lighting conditions on the habituation of pond-reared yellow perch (Perca flavescens) to intensive culture conditions. Aquaculture 104:67-88

Malison JA, Northey DL, Held JA, Kuczynski TE (1994) Habituation of yellow perch (Perca flavescens) fingerlings to formulated feeds in ponds using lights and vibrating feeders. World Aquaculture Society book of abstracts 25th annual meeting of the World Aquaculture Society, New Orleans

Martin BT, Wahl DH, Czesny SJ (2012) Effects of light intensity, prey density, and ontogeny on foraging success and prey selection of larval yellow perch (Perca flavescens). Ecol Freshw Fish 21:588-596

Mélard C, Baras E, Mary L, Kestemont P (1996) Relationships between stocking density, growth, cannibalism and survival rate in intensively cultured larvae and juveniles of perch (Perca fluviatilis). Ann Zool Fenn 33:643-651

Morris JE, Mischke CC (1999) Plankton management for fish culture ponds, vol 114, North Central Regional Aquaculture Center (NCRAC) technical bulletin series. North Central Regional Aquaculture Center Publications Office, Iowa State University, Ames 
Nash CE, Kuo CM, McConnel SC (1974) Operational procedure for rearing larvae of grey mullet (Mugil cephalus L.). Aquaculture 3:15-24

Neal JW, Kröger C (2012) Sportfish pond fertilization. In: Mischke CC (ed) Pond fertilization: impacts of nutrient input on aquaculture production. Wiley-Blackwell, Oxford, pp 245-258

Ostaszewska T (2005) Developmental changes of digestive system structures in pikeperch (Sander lucioperca L.). Electron J Ichthyol 2:65-78

Paller MH, Lewis WM (1987) Effects of diet on growth depensation and cannibalism among intensively cultured larval striped bass. Prog Fish Cult 49:270-275

Siefert RE (1972) First food of larval yellow perch, white sucker, bluegill, emerald shiner, and rainbow smelt. Trans Am Fish Soc 101:219-225

Soderberg RW (1977) Perch fingerling production for aquaculture. University of Wisconsin Sea Grant College Program, advisory report \#421, Madison

Soderberg RW (2012) Organic and inorganic fertilization. In: Mischke CC (ed) Pond fertilization: impacts of nutrient input on aquaculture production. Wiley-Blackwell, Oxford, pp 33-45

Summerfelt RC (1996) Intensive culture of walleye fry. In: Summerfelt RC (ed) Walleye culture manual, vol 101, NCRAC culture series. North Central Regional Aquaculture Center Publications Office, Iowa State University, Ames, pp 161-185

Tamazouzt L (1995) L'alimentation artificielle de la perche Perca fluviatilis en milieu confinés (eau recycle, cage flottante). Thèse de doctorat, Université H. Poincaré, Nancy, $128 \mathrm{p}$

Tamazouzt L, Chatain B, Fontaine P (2000) Tank wall color and light level affect growth and survival of Eurasian perch larvae (Perca fluviatilis L.). Aquaculture 182:85-90

Tice BJ, Soderberg RW, Kirby JM, Marcinko MT (1996) Growth and survival of walleyes reared in ponds fertilized with organic or inorganic materials. Prog Fish Cult 58:135-139

Wojno M, Kwasek K, Dabrowski K, Wick M (2012) Yellow perch rearing in intensive conditions -update for 2011. Lake Erie-Inland waters annual review, Ohio Division of Wildlife, Columbus, 26-27 Jan 